\title{
Scholing van werkenden : themarapport werkgelegenheid en scholing 1998
}

Citation for published version (APA):

de Grip, A., van Loo, J. B., \& de Steur, M. J. (1999). Scholing van werkenden : themarapport werkgelegenheid en scholing 1998. Researchcentrum voor Onderwijs en Arbeidsmarkt, Faculteit der Economische Wetenschappen. ROA Reports No. 3 https://doi.org/10.26481/umarep.1999003

Document status and date:

Published: 01/01/1999

DOI:

10.26481/umarep.1999003

Document Version:

Publisher's PDF, also known as Version of record

\section{Please check the document version of this publication:}

- A submitted manuscript is the version of the article upon submission and before peer-review. There can be important differences between the submitted version and the official published version of record.

People interested in the research are advised to contact the author for the final version of the publication, or visit the DOI to the publisher's website.

- The final author version and the galley proof are versions of the publication after peer review.

- The final published version features the final layout of the paper including the volume, issue and page numbers.

Link to publication

\footnotetext{
General rights rights.

- You may freely distribute the URL identifying the publication in the public portal. please follow below link for the End User Agreement:

www.umlib.nl/taverne-license

Take down policy

If you believe that this document breaches copyright please contact us at:

repository@maastrichtuniversity.nl

providing details and we will investigate your claim.
}

Copyright and moral rights for the publications made accessible in the public portal are retained by the authors and/or other copyright owners and it is a condition of accessing publications that users recognise and abide by the legal requirements associated with these

- Users may download and print one copy of any publication from the public portal for the purpose of private study or research.

- You may not further distribute the material or use it for any profit-making activity or commercial gain

If the publication is distributed under the terms of Article $25 \mathrm{fa}$ of the Dutch Copyright Act, indicated by the "Taverne" license above, 
Scholing van werkenden

\section{Themarapport \\ Werkgelegenheid en scholing 1998}

ROA-R-1999/3

Andries de Grip

Jasper van Loo

Margot de Steur

Researchcentrum voor Onderwijs en Arbeidsmarkt

Faculteit der Economische Wetenschappen en Bedrijfskunde

Universiteit Maastricht

Maastricht, februari 1999 
ISBN 90-5321-250-7

SEC98.243/JVL 


\section{Inhoud}

Bladzijde

Voorwoord

Resumé

1 Inleiding 1

1.1 Inleiding 1

1.2 Opzet van het rapport 2

2 Scholing van werkenden 3

2.1 Inleiding 3

2.2 Waarom scholing ter voorkoming van kwalificatieveroudering: werknemers

2.3 Waarom scholing ter voorkoming van kwalificatieveroudering: bedrijven

2.4 De betekenis van scholing voor werknemers 6

2.5 De betekenis van scholing voor bedrijven 13

$\begin{array}{lr}2.6 \text { Samenvatting en conclusie } & 15\end{array}$

3 Risicofactoren en kwalificatieveroudering $\quad 17$

$\begin{array}{ll}3.1 \text { Inleiding } & 17\end{array}$

$\begin{array}{ll}3.2 \text { Slijtage } & 19\end{array}$

$\begin{array}{ll}3.3 \text { Atrofie } & 23\end{array}$

3.4 Functie-inhoudelijke kwalificatieveroudering 23

3.5 Kwalificatieveroudering door marktontwikkelingen en
bedrijfsspecifieke kwalificatieveroudering

$\begin{array}{ll}3.6 \text { Conclusies } & 32\end{array}$

4 Doelgroepen voor scholingsbeleid 35

$\begin{array}{ll}4.1 \text { Inleiding } & 35\end{array}$

4.2 Samenhang tussen de verschillende scholings- en
employability-variabelen

4.3 Doelgroepen voor het scholingsbeleid als gevolg van
functie-Inhoudelijke kwalificatieveroudering

$\begin{array}{ll}4.4 \text { Conclusies } & 41\end{array}$

5 Conclusies $\quad 43$

$\begin{array}{ll}\text { Literatuur } & 45\end{array}$

$\begin{array}{ll}\text { Bijlage: Statistische Analyses } & 47\end{array}$ 
..... 


\section{Voorwoord}

Scholing van werkenden is het tweede thema-rapport in het kader van het Werkgelegenheid en Scholing Observatorium (WSO) van het Researchcentrum voor Onderwijs en Arbeidsmarkt (ROA). Dit observatorium is door het Ministerie van Sociale Zaken en Werkgelegenheid ingesteld in het kader van de stimuleringsprogramma's ESF-4 Scholing voor behoud van werk en ADAPT van de Europese Commissie.

Het observatorium heeft als doel de voor het scholingsbeleid relevante ontwikkelingen op continue basis in beeld te brengen. Het WSO fungeert daarbij als een centraal punt, waar de relevante ontwikkelingen en prognoses met betrekking tot de werkgelegenheid en kwalificatiebehoeften met elkaar in verband worden gebracht, om zo tijdig inzicht te krijgen in de scholingsactiviteit binnen branches en bedrijven en de lacunes die op dit punt bestaan.

In de twee jaar-rapportages van het WSO (Werkgelegenheid en Scholing 1996 en Werkgelegenheid en Scholing 1997) is de WSO-thematiek integraal in beeld gebracht. Dit themarapport heeft daarentegen een ander doel. Enerzijds gaat het om het verkrijgen van een beter inzicht in de rol die scholing kan spelen bij het voorkomen van kwalificatieveroudering; anderzijds gaat het om een empirische onderbouwing van een aantal in het WSO-raamwerk veronderstelde relaties tussen kwalificatieveroudering, risicofactoren en scholingsparticipatie en employability. Op basis van de uitkomsten van die empirische analyses kan het theoretisch raamwerk en de methodiek van de volgende WSO-rapportage wellicht verbeterd worden.

De leiding van dit project was in handen van dr. A. de Grip. Daarnaast is aan het onderzoek meegewerkt door drs. J.B. van Loo en drs. M.J. de Steur. Onze dank gaat uit naar de leden van de begeleidingscommissie. Deze commissie bestaat uit de volgende leden: drs. M.G. Drewes, drs. F. Straatjes en drs. J.C. van der Velden. 


\section{Resumé}

Scholing van werkenden is het tweede thema-rapport van het Werkgelegenheid en Scholing Observatorium (WSO) 1998. In de eerder uitgebrachte WSO-jaarrapportages (De Grip c.s. 1997a/b, en ROA, 1998a/b) is de WSO-thematiek, gericht op het in kaart brengen van de risico's op verlies van werk en de betekenis van scholingsactiviteiten ter verbetering van de perspectieven, integraal in beeld gebracht. Dit thema-rapport heeft een ander karakter. Het is enerzijds een onderzoek naar enkele centrale veronderstellingen uit het WSO-model en anderzijds een verdieping van de vraag wat de betekenis van scholing is voor bedrijven en de werknemer zelf. Het doel van het rapport is om verbeteringen in de methodiek, die in de volgende jaarrapportage gebruikt kunnen worden, aan te reiken.

\section{De betekenis van scholing bij het tegengaan van kwalificatieveroudering}

De scholing van werkenden speelt een centrale rol in het WSO-model. Het gaat daarbij om scholing die gericht is op het tegengaan van kwalificatieveroudering. Scholing is echter niet het enige instrument om dat te bereiken. Zo hebben werknemers in principe drie opties om met kwalificatieveroudering om te gaan. Ze kunnen veranderen van baan, de arbeidsmarkt helemaal verlaten of investeren in hun eigen kennis en vaardigheden om hun kwalificaties op peil te houden. De eerste mogelijkheid is gegeven de reikwijdte van bepaalde maatschappelijke ontwikkelingen die tot kwalificatieveroudering kunnen leiden (zoals bijvoorbeeld de in alle sectoren voortschrijdende informatisering), slechts voor weinig werknemers een reële optie. De arbeidsmarkt verlaten is alleen voor werknemers die gebruik kunnen maken van specifieke uittredingsfaciliteiten (V.U.T.-regelingen, e.d.) aanvaardbaar. Voor de meeste andere werknemers is de met uittrede gepaard gaande inkomensdaling echter nagenoeg onacceptabel of te groot. De derde optie wordt daardoor steeds belangrijker: het volgen van scholing wordt het belangrijkste instrument om de kwalificatieveroudering, die het gevolg is van de verschillende ontwikkelingen die op werknemers afkomen, te lijf te gaan.

Bedrijven kunnen de problemen die optreden als gevolg van kwalificatieveroudering bij hun personeel ook op verschillende manieren oplossen. Zo zou een bedrijf bijvoorbeeld werknemers voor een beperkte tijd kunnen aannemen en ze weer ontslaan wanneer hun kwalificaties tekort beginnen te schieten. Deze optie wordt echter steeds moeilijker in de praktijk uit te voeren gezien de demografische tendensen (ontgroening en vergrijzing) in de beroepsbevolking en het feit dat de snelle technologische en organisatorische ontwikkelingen ervoor zorgen dat werknemers die geen aanvullende scholing volgen vaak al na korte tijd niet meer voldoende productief zijn. Al met al nopen deze ontwikkelingen bedrijven ertoe, zich te richten op het investeren in het menselijk kapitaal van hun medewerkers. 
Naast de vraag waarom scholing zo'n belangrijk instrument is bij het tegengaan van kwalificatieveroudering kan er ook gekeken worden naar de betekenis van scholing die gericht is op het tegengaan van kwalificatieveroudering. Voor werknemers heeft het volgen van dergelijke scholing drie mogelijke effecten: het voorkomen van kwalificatieveroudering, loopbaaneffecten en inkomenseffecten.

De effecten voor bedrijven van scholing die kwalificatieveroudering van werknemers vermindert, kunnen zowel bekeken worden door te kijken naar de invloed op het productieproces als naar de bedrijfsprestaties. Uit empirisch onderzoek blijkt dat zowel de productiviteit als ook de bedrijfsprestaties positief samenhangen met de scholingsintensiteit.

\section{Risicofactoren en kwalificatieveroudering}

Een centrale veronderstelling uit het WSO-instrumentarium is dat risicofactoren waarmee werknemers geconfronteerd worden leiden tot kwalificatieveroudering en dat scholing en een goede employability hier tegenwicht aan kunnen bieden. Deze veronderstelling wordt getoetst door voor iedere vorm van kwalificatieveroudering een analyse uit te voeren die het risico op kwalificatieveroudering relateert aan enerzijds het optreden van risicofactoren en anderzijds de scholing en de employability van de werkenden. Uit deze analyses komen de volgende resultaten naar voren.

Het optreden van slijtage blijkt positief samen te hangen met belastende arbeidsomstandigheden. Daarnaast hebben oudere werknemers een grotere kans op slijtage dan jongeren en hebben werknemers met een hoger beroepsniveau een kleinere kans op slijtage dan werknemers die een beroep op een laag niveau hebben. Scholing en de employability van werkenden zijn nauwelijks van belang bij het voorkomen van slijtage. Mobiliteitsbereidheid is de enige significante variabele, maar deze blijkt de kans op slijtage te vergroten. Dit is niet volgens de verwachting. Het feit dat werknemers die aangeven uit te zien naar een andere baan, dat ook vaak doen omdat ze de huidige werksituatie niet meer aankunnen, speelt hier mogelijk een rol.

Uit de analyses blijkt verder dat het risico op functie-inhoudelijke kwalificatieveroudering, zoals dat ook in het WSO-model verondersteld wordt, significant samenhangt met een aantal maatschappelijke ontwikkelingen. Daarbij blijken drie van de vier onderzochte ontwikkelingen het risico op functie-inhoudelijke kwalificatieveroudering te vergroten. Het gaat hier om de technologische ontwikkelingen, de organisatorische vernieuwingen en de vergrijzing van de werkzame bevolking. Het mobiliteitsvermogen en de opleidingsbereidheid (gebaseerd op het aantal gevolgde aanvullende cursussen) blijken de kans op functie-inhoudelijke kwalificatieveroudering te verminderen. Het opleidingsvermogen (de totale opleidingsduur van 
de initiële opleiding en de gevolgde cursussen) heeft daarentegen geen significant effect. Dit duidt erop dat met name het volgen van cursussen een belangrijk middel is om kwalificatieveroudering door technologische, organisatorische of demografische ontwikkelingen te voorkomen.

Het risico op kwalificatieveroudering door marktontwikkelingen dat zich uit door een hogere uitstroom van werkenden naar werkloosheid of niet-participatie wordt inderdaad vergroot door de werkgelegenheidskrimp per opleidingstype. Werknemers met een flexibel arbeidscontract blijken hierbij een verhoogd risico te lopen, aangezien zij veelal de eersten zijn waarvan het contract wordt beëindigd in geval van krimpende werkgelegenheid. Verder zijn drie van de opleidings- en employability-variabelen van belang bij het verminderen van dit risico op kwalificatieveroudering. Zowel opleidingsbereidheid, mobiliteitsbereidheid als de bereidheid tot brede inzetbaarheid verkleinen de kans op uitstroom naar werkloosheid of niet-participatie.

In de analyse waar de kwalificatieveroudering gemeten wordt door een verslechtering van de aansluiting tussen iemands kwalificaties en zijn of haar huidige baan, kan er zowel sprake zijn van kwalificatieveroudering door marktontwikkelingen als van bedriffsspecifieke kwalificatieveroudering. Uit de analyse komt naar voren dat een verandering van bedrijf, een verandering van beroep en bedrijf en een verandering van beroep, sector en bedrijf alle drie de kans op kwalificatieveroudering vergroten, waarbij laatstgenoemde verandering het grootste effect heeft. Het beroepsniveau heeft daarentegen een tegengesteld effect: werknemers met een hogere functie lopen minder risico op kwalificatieveroudering dan werknemers met een lage functie. Scholings- en employability-variabelen leiden daarentegen niet tot een vermindering van het risico op kwalificatieveroudering door marktontwikkelingen of bedrijfswisselingen. Wel blijkt het aantal cursussen dat iemand in het verleden heeft gevolgd de kans op deze vorm van kwalificatieveroudering te beïnvloeden. In tegenstelling tot het verwachte negatieve verband blijkt het aantal gevolgde cursussen echter de kans op kwalificatieveroudering te vergroten. Een mogelijke verklaring hiervoor is dat het juist de werkenden zijn die al problemen hebben cursussen gaan volgen en dat scholing in onvoldoende mate een preventieve remedie is voor kwalificatieveroudering. Scholing heeft in dit geval derhalve eerder een curatief dan een preventief karakter.

\section{Doelgroepen voor scholingsbeleid}

Uit de empirische analyses volgt een aantal bruikbare resultaten dat gebruikt kan worden om de methodiek voor het bepalen van doelgroepen voor het scholingsbeleid te verfijnen en verbeteren. Deze resultaten hebben betrekking op de aard van de risicofactoren die kwalificatieveroudering in de hand werken en de scholings- en employability-variabelen die bepaalde vormen van kwalificatieveroudering kunnen tegengaan. Ook de relatie tussen scholing en employability wordt empirisch onder- 
zocht en levert nieuwe inzichten op. Zo blijkt bijvoorbeeld dat er geen eenduidige relatie tussen scholing en employability kan worden afgeleid, wat inhoudt dat enige terughoudendheid geboden is bij het opleggen van de restrictie dat bepaalde groepen werkenden alleen een doelgroep vormen voor het scholingsbeleid gericht op behoud van werk als zowel scholingsparticipatie als employability tekortschieten. Vervolgens zijn er, op basis van de nieuwe inzichten, doelgroepen voor scholingsbeleid geïdentificeerd voor werkenden die te kampen hebben met functie-inhoudelijke kwalificatieveroudering. De nieuwe methodiek leidt tot doelgroepen die deels verschillen maar zeker ook een bepaalde mate van overlap vertonen met de eerder in het rapport Werkgelegenheid en scholing 1997 geïdentificeerde doelgroepen voor het scholingsbeleid gericht op het behoud van werk. Zo is bijvoorbeeld meer dan de helft van de in dit rapport geïdentificeerde doelgroepen naar beroepssegment ook doelgroep wanneer de methodiek uit WSO 1997 wordt gebruikt.

In principe kunnen er ook voor andere vormen van kwalificatieveroudering op een dergelijke wijze de doelgroepen voor het scholingsbeleid gericht op behoud van werk worden bepaald. Bij de toepassing van de methodiek op de overige vormen van kwalificatieveroudering dient echter wel het voorbehoud te worden gemaakt dat hiervoor erg gedetailleerde data zijn vereist. 


\section{Inleiding}

\subsection{Inleiding}

De ontwikkelingen die de laatste jaren plaatsvinden in de maatschappij doen een steeds groter beroep op werknemers om hun positie op de arbeidsmarkt te handhaven. Het gaat hier om demografische, technologische, organisatorische en economische ontwikkelingen. Deze veranderingen kunnen ertoe leiden dat de kwalificaties van werknemers snel in waarde verminderen. Om de kwalificaties op peil te houden kan scholing een belangrijke rol spelen. Maar niet alleen het up-to-date houden van kennis en vaardigheden is in dit kader van belang. Ook de employability van de werkenden speelt hierbij een belangrijke rol. Employability wordt gedefinieerd als het in staat zijn en de wens hebben blijvend aantrekkelijk te zijn voor de arbeidsmarkt, door te reageren en te anticiperen op veranderingen in arbeidstaken en werkomgeving. Werknemers die 'employable' zijn, kunnen dus beter met veranderingen omgaan.

In het theoretisch model dat ten grondslag ligt aan het Werkgelegenheid en scholing observatorium, WSO (zie ROA, 1998a/b) komen al deze factoren aan de orde. Het minder waard worden van kwalificaties wordt kwalificatieveroudering genoemd. Hierbij wordt een aantal vormen van kwalificatieveroudering onderscheiden. Het gaat achtereenvolgens om slijtage, atrofie, functie-inhoudelijke kwalificatieveroudering, kwalificatieveroudering door marktontwikkelingen en bedrijfsspecifieke kwalificatieveroudering.

In de integrale rapportages van het WSO (De Grip, c.s. 1997a/b en ROA, 1998a/b) zijn er ten aanzien van kwalificatieveroudering in het onderliggende theoretische model een aantal vereenvoudigende veronderstellingen gehanteerd. Zo wordt bijvoorbeeld aangenomen dat scholingsactiviteiten en/of een 'employable' werkhouding kwalificatieveroudering bij werknemers tegengaan. Ook wordt impliciet verondersteld dat er sprake is van een directe relatie tussen het bestaan van bepaalde risico's voor werknemers en het optreden van kwalificatieveroudering.

Daarnaast is er in voorafgaande WSO-rapporten weinig aandacht besteed aan de factoren die van invloed zijn op de scholingsdeelname van werknemers en aan de vraag wat de betekenis van scholing is voor bedrijven en de werknemers zelf. Ook de verschillende soorten scholing en de verschillende vormen ervan zijn slechts in de marge genoemd.

Een verdere uitdieping van de onderliggende veronderstellingen in het WSO-model kan de bestaande WSO-methodiek verbeteren. Vandaar dat een aantal van de in de WSO-methodiek gehanteerde vooronderstellingen getoetst zullen worden. Daarnaast is inzicht in de betekenis van scholing in het kader van het voorkomen van 
kwalificatieveroudering van belang. De resultaten van dit rapport kunnen het conceptuele WSO-model verbeteren en zullen waar mogelijk verwerkt worden in de volgende rapportage van het WSO.

\subsection{Opzet van het rapport}

De verdere opzet van het rapport is als volgt. In hoofdstuk 2 wordt eerst een overzicht gegeven van de literatuur die betrekking heeft op de scholing van werkenden. De nadruk wordt daarbij gelegd op scholing die tot doel heeft kwalificatieveroudering te voorkomen of de effecten daarvan te verminderen. Er zal zowel aandacht worden geschonken aan de aanleiding voor als ook de betekenis van op het verminderen of voorkomen van kwalificatieveroudering gerichte scholing, voor werknemers en bedrijven.

De twee daarop volgende hoofdstukken bevatten een aantal empirische toetsen van de veronderstelde relaties binnen het WSO-model. In hoofdstuk 3 zal onderzocht worden of en in hoeverre kwalificatieveroudering verklaard kan worden door het optreden van bepaalde risico-factoren. In dit hoofdstuk wordt ook onderzocht welke scholings- en employability-aspecten kwalificatieveroudering kunnen tegengaan.

In hoofdstuk vier komt de relatie tussen scholing en employability en het bepalen van de doelgroepen voor het scholingsbeleid gericht op het behoud van werk aan de orde. Voor functie-inhoudelijke kwalificatieveroudering zal, op basis van de gevonden verbanden in hoofdstuk 3 , worden nagegaan hoe de bepaling van doelgroepen het beste kan plaatsvinden. Het laatste hoofdstuk (hoofdstuk 5) zal de belangrijkste conclusies van dit rapport bevatten. 


\section{Scholing van werkenden}

\subsection{Inleiding}

In dit hoofdstuk zal aan de hand van zowel empirische als ook theoretische literatuur de scholing van werkenden worden belicht. Gezien het centrale thema in het WSO zal de rol van scholing bij het voorkomen of verminderen van kwalificatieveroudering centraal staan. Daarbij zal er achtereenvolgens ingegaan worden op de vraag waarom scholing gevolgd wordt en wat de betekenis van scholing is, voor zowel werknemers als bedrijven.

Scholing zal hierbij telkens vanuit twee invalshoeken worden belicht. Zowel het perspectief van de werknemer als ook de positie van het bedrijf ${ }^{1}$ (c.q. de werkgever) komt in dit hoofdstuk aan de orde. Scholing zal hierbij nogal ruim gedefinieerd worden. Het gaat om alle 'bedoelde' activiteiten ${ }^{2}$ die de competenties van werkenden op peil houden of vergroten. Het gaat dus niet alleen om formeel georganiseerde opleidingen of cursussen, maar ook om on-the-job training en andere manieren van leren. Het moet echter telkens wel gaan om intentionele scholing; onbedoelde externe effecten die het gevolg zijn van het productieproces of de organisatie waardoor de competenties van werkenden worden vergroot, worden daarom niet tot scholing gerekend. Er wordt bijvoorbeeld niet ingegaan op 'learning by doing', waarmee wordt aangegeven dat naarmate werknemers langer eenzelfde functie uitoefenen, ze productiever worden (Arrow, 1962).

Zoals al eerder opgemerkt, gaat het hier om scholing die als doel heeft kwalificatieveroudering te voorkomen of tegen te gaan. Er zal telkens een onderscheid worden gemaakt tussen de reden waarom juist scholing als instrument wordt ingezet en de betekenis van scholing. Beide aspecten worden zowel vanuit het perspectief van werknemers als ook vanuit het perspectief van bedrijven benaderd. De verdere opzet van het hoofdstuk is als volgt. In paragraaf 2.2 wordt er ingegaan op de vraag waarom werknemers scholing volgen. In paragraaf 2.3 komt de vraag waarom bedrijven scholing stimuleren aan de orde. Daarna wordt er in de paragrafen 2.4 en 2.5 achtereenvolgens ingegaan op de betekenis van scholing voor werknemers en bedrijven. Paragraaf 2.6 sluit het hoofdstuk af met een samenvatting en enkele conclusies.

1. Wanneer er over bedrijven gesproken wordt, betreft het ook de niet-commerciële organisaties en de overheidsinstellingen.

2. Daarmee raakt het ook de kern van het zogenaamde Human Resource Development (zie ook Thijssen, 1997) 


\subsection{Waarom scholing ter voorkoming van kwalificatieveroudering: werknemers}

Technologische, organisatorische, demografische en economische ontwikkelingen en arbeidsmarktontwikkelingen dragen er toe bij dat kennis en vaardigheden verouderen. $\mathrm{Er}$ is een aantal manieren waarop werknemers op dergelijke ontwikkelingen kunnen reageren:

1 change: veranderen van baan;

2 leave: de arbeidsmarkt verlaten;

3 invest: het volgen van opleidingen e.d. om het eigen menselijk kapitaal te vergroten.

De eerste optie kan worden gerelateerd aan de zogenaamde 'job-matching' theorie (zie De Grip c.s., 1990). Volgens deze theorie heeft het veranderen van baan (mobiliteit) als doel het verbeteren van de 'match' tussen iemands kwalificaties en de baan die de betrokkene uitoefent. Wanneer bepaalde ontwikkelingen de match tussen de kwalificaties en baan verslechteren, bestaat de optie om ander werk te gaan zoeken. Deze optie is in de praktijk echter vaak moeilijk te realiseren. Het blijkt dat bepaalde ontwikkelingen (bijvoorbeeld informatisering en psychische belasting) de werkenden in zeer uiteenlopende beroepen raken (ROA, 1998a/b). Daarmee wordt de kans om een baan te vinden waarin de met de desbetreffende vorm van kwalificatieveroudering geassocieerde risicofactoren geen rol spelen erg klein.

De tweede mogelijkheid om te reageren op de ontwikkelingen die kennis en vaardigheden verouderen, is het verlaten van de arbeidsmarkt. Deze optie is vooral relevant voor oudere werknemers, die bijvoorbeeld gebruik kunnen maken van vervroegde uittredingsfaciliteiten, e.d. Aangezien de met arbeidsmarktuittrede gepaardgaande inkomensdaling echter voor de meeste andere werknemers waarschijnlijk onaanvaardbaar is, is het voor hen geen reële optie. Alleen bij kwalificatieveroudering vanwege slijtage is uitstroom naar de WAO vanuit werknemersoptiek doorgaans (noodgedwongen) een reële optie.

De derde optie, scholing, is voor grote groepen werkenden erg belangrijk bij het omgaan met de diverse ontwikkelingen die op hen afkomen. Overigens kunnen werknemers ook andere beweegredenen hebben om scholing te volgen (zie ook Dekker c.s., 1995). Zo kunnen werknemers bijvoorbeeld loopbaangerichte scholing volgen die met name gericht is op de voorbereiding voor toekomstige, hogere functies. Hierop zal in dit hoofdstuk niet verder worden ingegaan. Het motief dat hier centraal staat, is het kunnen omgaan met veranderingen die kwalificatieveroudering kunnen veroorzaken. Als werknemers niet voldoende aandacht aan scholing besteden, dan lopen ze het risico op kwalificatie-veroudering, waardoor ze hun baan zouden kunnen verliezen. 


\subsection{Waarom scholing ter voorkoming van kwalificatieveroudering: bedrijven}

Het menselijk kapitaal speelt in het productieproces van veel bedrijven een steeds belangrijkere rol (OECD, 1996). Er is sprake van een overgang van een industriële productiestructuur naar een productiesysteem dat ook wel als een 'kenniseconomie' aangeduid wordt (zie bijvoorbeeld Kessels, 1996). Deze overgang wordt met name geassocieerd met technologische, organisatorische, economische en demografische ontwikkelingen (De Grip c.s., 1998a/b). Veel van deze maatschappelijke ontwikkelingen gaan in een steeds sneller tempo. Dat vergroot het risico op kwalificatieveroudering bij het personeel en vereist van bedrijven dat ze inspanningen moeten leveren om de kennis en vaardigheden van hun personeel up-to-date te houden. Om dat te bereiken kunnen bedrijven een aantal strategieën nastreven (zie ook De Grip c.s., $1997 \mathrm{a} / \mathrm{b})$ :

1 make: het werven van laag opgeleid personeel en het daarnaast fors investeren in de scholing van het personeel;

2 buy: het aannemen van hoog opgeleid personeel, maar geen aanvullende scholing aanbieden;

3 squeeze: het niet of nauwelijks scholen van het personeel dat ook in het initieel onderwijs slechts een lage opleiding heeft gevolgd;

4 accumulate: het werven van hoog opgeleid personeel en het daarnaast nog verder investeren in hun scholing.

Diverse ontwikkelingen op de arbeidsmarkt maken de tweede en de derde optie steeds onaantrekkelijker en moeilijker uit te voeren. Het gaat daarbij met name om de ontgroenings- en vergrijzingstendensen in de beroepsbevolking. Deze ontwikkelingen hebben tot gevolg dat de instroom van schoolverlaters beperkter wordt en de beroepsbevolking veroudert. Als gevolg daarvan zal het in de toekomst moeilijker worden om voldoende nieuw gekwalificeerd personeel aan te trekken. Daarnaast zorgen de snelle technologische en organisatorische ontwikkelingen ervoor dat de periode waarin het personeel zonder aanvullende scholing nog voldoende productief is, korter wordt. Vandaar dat de nadruk steeds meer komt te liggen op het om- en bijscholen van het bestaande personeel (zie ook Tuijnman, 1997).

De 'make' en de 'accumulate' strategieën staan daarom momenteel erg in de belangstelling. Steeds meer bedrijven realiseren zich dat het voortdurend investeren in het menselijk kapitaal van hun personeel de manier is om actief te kunnen blijven op de markten waarop zij opereren (zie ook ILO, 1995).

Eén en ander leidt er toe dat scholing van werkenden vaak een speerpunt in het strategisch beleid van bedrijven wordt. Het scholingsbeleid hangt ook vaak sterk samen met andere aspecten van het strategisch beleid. Uit onderzoek blijkt dat scholing vaak onderdeel vormt van een bedrijfsstrategie die gericht is op innovatie 
en 'total quality management' (Baldwin en Johnson, 1995). Om een effectief trainingsprogramma op te zetten is het immers van groot belang de inhoud en de kernpunten af te stemmen op de strategie van de organisatie (Carnevale c.s., 1990).

\subsection{De betekenis van scholing voor werknemers}

Wanneer een werknemer scholing volgt die als primair doel heeft om kwalificatieveroudering tegen te gaan, kan dat een aantal effecten hebben:

- De gevolgde scholing gaat kwalificatieveroudering tegen;

- De gevolgde scholing heeft (op de lange termijn) positieve effecten op de loopbaan;

- De gevolgde scholing heeft positieve effecten op het inkomen van de werknemer.

Om te kunnen komen tot een analyse van deze effecten wordt er hier in eerste instantie gekeken naar twee belangrijke invloedsfactoren, die de effecten van de gevolgde scholing in belangrijke mate bepalen. Allereerst wordt er aandacht besteed aan het karakter van de competenties (kennis en vaardigheden) die door de scholing worden aangeleerd. Dat zal gebeuren door te kijken naar de breedte van de competenties. Een andere factor die van belang is, is de aard van de mobiliteit die een werknemer in zijn of haar loopbaan kan verwachten. Daarna wordt er ingegaan op de drie genoemde effecten van scholing die gericht is op het voorkomen van kwalificatieveroudering.

\section{Breedte van competenties}

De mogelijke effecten van scholing die gericht is op het tegengaan van kwalificatieveroudering zijn gerelateerd aan de breedte van de kennis en vaardigheden (competenties) die door een opleiding worden aangeleerd. De breedte van competenties kan gemeten worden door drie specificiteits-dimensies, te weten (Nordhaug, 1993):

- taakspecificiteit;
- bedrijfspecificiteit;
- $\quad$ sectorspecificiteit.

Taakspecificiteit is de mate waarin een bepaalde competentie in verschillende taken kan worden toegepast. De bedrijfsspecificiteit van competenties meet in hoeverre vaardigheden gebruikt kunnen worden in een ander bedrijf in dezelfde sector. Ten slotte kunnen competenties gekarakteriseerd worden naar de mate waarin vaardigheden in verschillende bedrijfssectoren gebruikt kunnen worden, de sectorspecificiteit. De drie genoemde specificiteits-dimensies kunnen gebruikt worden om de competenties die door scholing worden aangeleerd te karakteriseren. Nordhaug 
(1993) werkt dit uit tot het overzicht zoals dat wordt gepresenteerd in tabel 2.1. Daarbij wordt voor iedere competentie (in cursief) een voorbeeld gegeven.

Meta-competenties worden gekenmerkt door een lage specificiteit op alle vlakken. Het zijn competenties die in een groot aantal verschillende taken, bedrijven en bedrijfssectoren gebruikt kunnen worden. Het gaat om algemene vaardigheden zoals bijvoorbeeld analytisch vermogen, kennis van vreemde talen, communicatieve vaardigheden en sociale vaardigheden.

Sector-competenties zijn competenties die een lage taak- en bedrijfsspecificiteit hebben, maar specifiek zijn voor een bepaalde bedrijfssector. Het gaat om zaken als kennis over de structuur van de bedrijfssector, het vermogen om acties van concurrenten te analyseren en kennis over belangrijke personen, netwerken en allianties in de bedrijfssector.

Competenties die bedrijfs- en bedrijfssectorspecifiek zijn, maar tegelijkertijd in een aantal verschillende taken kunnen worden gebruikt zijn intra-organisatie-competenties. Dit soort competenties kunnen worden opgevat als 'bedrijfsspecifieke metacompetenties'. Voorbeelden van dit soort competenties zijn kennis over collega's, de organisatiecultuur, informele netwerken en de bedrijfsstrategie.

Tabel 2.1

Classificatie van competenties volgens 3 specificiteitsdimensies: taakspecificiteit, bedrijfsspecificiteit en sectorspecificiteit

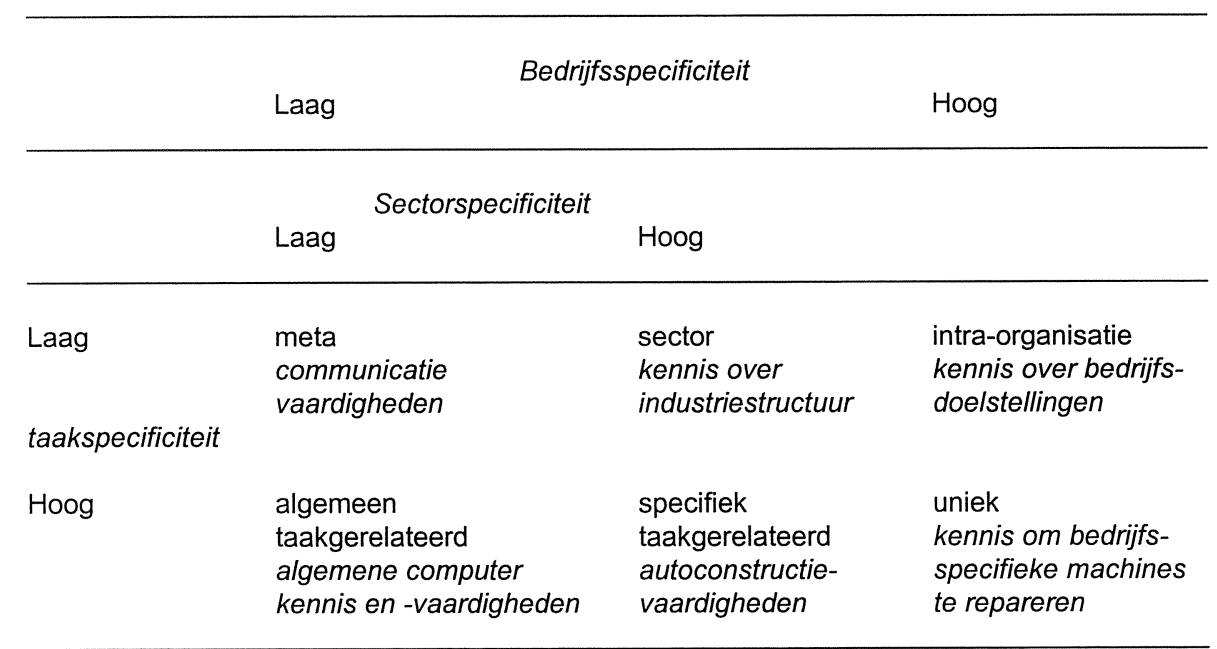

Bron: Nordhaug, 1993

Algemeen taakgerelateerde competenties hebben een hoge taakspecificiteit, en een lage bedrijfs- en bedrijfssectorspecificiteit. Het zijn technische (handelingsgerichte) competenties zoals bijvoorbeeld tekstverwerking, boekhouden, kennis van standaard computersoftware en vakkennis. 
Specifiek taakgerelateerde competenties zijn taak en bedrijfssector specifiek, maar niet bedrijfsspecifiek. Voorbeelden zijn vaardigheden die nodig zijn bij het bouwen van auto's, vliegtuigen en het construeren van personal computers.

Taak- en bedrijfs- (en dus ook bedrijfssector-) specifieke competenties worden unieke competenties genoemd. Dit soort competenties is in wezen volledig specifiek menselijk kapitaal (Becker, 1980). Het zijn vaardigheden zoals het gebruik van gespecialiseerd gereedschap, het omgaan met machines die 'taylor made' voor het bedrijf zijn en de specifieke administratieve procedures binnen een bedrijf.

\section{Mobiliteitsmogelijkheden}

Een tweede belangrijke factor die de effecten van scholing die gericht is op het tegengaan van kwalificatieveroudering beïnvloedt, zijn de mobiliteitsmogelijkheden. Mobiliteitsmogelijkheden kunnen worden omschreven als de mogelijkheden die werknemers hebben om intern (binnen het bedrijf waar men werkzaam is) of extern (tussen bedrijven en bedrijfssectoren) mobiel te zijn. Deze mogelijkheden worden voornamelijk bepaald door de kenmerken van de baan en het bedrijf waarin men werkzaam is. Op basis van deze kenmerken wordt de arbeidsmarkt als geheel vaak in een drietal segmenten opgesplitst, namelijk (zie bijvoorbeeld Dekker c.s., 1995):

- bedrijfsinterne arbeidsmarkten;

- vakdeelmarkten;

- secundaire arbeidsmarkt.

In tabel 2.2 wordt een overzicht gegeven van de kenmerken van de drie bovengenoemde arbeidsmarktsegmenten en de voor ieder segment relevante mobiliteitsmogelijkheden.

Interne arbeidsmarkten zijn vaak te vinden in grote, kapitaalintensieve bedrijven. Die bedrijven vragen van hun werknemers bedrijfsspecifieke vaardigheden. Binnen bedrijven met een interne arbeidsmarkt is er een scheiding tussen intredefuncties ('ports of entry') en vervolgfuncties. De scholing die bedrijven met interne arbeidsmarkten aan hun werknemers aanbieden is veelal bedrijfsspecifiek. De verkregen kennis moet door de ervaren werknemers aan nieuwkomers worden overgedragen. Zij zullen dat echter alleen doen als hun eigen positie daardoor niet in het gedrang komt door concurrentie van nieuwkomers. Vandaar dat de (interne) mobiliteitsmogelijkheden worden bepaald door (vaak op senioriteit gebaseerde) formele regels en dat de arbeidsvoorwaarden goed zijn op interne arbeidsmarkten. Het laatste uit zich bijvoorbeeld in het grote aandeel van vaste arbeidscontracten.

Vakdeelmarkten hebben vooral betrekking op functies waarvoor een beroeps- of vakspecifieke scholing vereist is. $\mathrm{Er}$ is op die markten een sterke relatie tussen het 
beroep waarin men werkzaam is en de gevolgde opleiding, terwijl er sprake is van een geringe binding met het bedrijf waarin men werkzaam is. De werknemers op vakdeelmarkten hebben, gezien hun vakspecifieke deskundigheid, een machtspositie, waardoor hun positie in het algemeen beter is dan die van de werknemers zonder vakspecifieke vaardigheden in het secundaire arbeidssegment. Eén en ander impliceert dat de mobiliteitsmogelijkheden met name extern zijn.

Tabel 2.2

Arbeidsmarktsegmenten, kenmerken van werkenden en bedrijven en mobiliteitsmogelijkheden

\begin{tabular}{|c|c|c|c|}
\hline Segment & Werkenden & $\begin{array}{l}\text { enmerken } \\
\text { Bedrijven }\end{array}$ & $\begin{array}{l}\text { Mobiliteits- } \\
\text { mogelijkheden }\end{array}$ \\
\hline $\begin{array}{l}\text { Interne } \\
\text { Arbeidsmarkt }\end{array}$ & $\begin{array}{l}\text {-bedrijfsspecifieke } \\
\text { vaardigheden } \\
\text {-verantwoordelijk } \\
\text { voor overdracht } \\
\text { van kennis op } \\
\text { nieuwkomers } \\
\text {-ondervertegen- } \\
\text { woordiging jongeren }\end{array}$ & $\begin{array}{l}\text {-scheiding tussen } \\
\text { intrede- en vervolg } \\
\text { functies } \\
\text {-bedrijfsspecifieke } \\
\text { training } \\
\text {-grote kapitaalintensieve } \\
\text { bedrijven } \\
\text {-lange arbeidscontracten }\end{array}$ & $\begin{array}{l}\text {-interne promotie- } \\
\text { mogelijkheden volgens } \\
\text { formele regels }\end{array}$ \\
\hline Vakdeelmarkt & $\begin{array}{l}\text {-beroeps- of vak- } \\
\text { specifieke scholing }\end{array}$ & $\begin{array}{l}\text {-veelal professionele } \\
\text { diensten } \\
\text {-sterke relatie tussen } \\
\text { beroep en opleiding maar } \\
\text { geringe bedrijfsbinding }\end{array}$ & $\begin{array}{l}\text {-externe mobiliteit } \\
r\end{array}$ \\
\hline $\begin{array}{l}\text { Secundaire } \\
\text { Arbeidsmarkt }\end{array}$ & $\begin{array}{l}\text {-laaggeschoolden } \\
\text {-groepen met lossere } \\
\text { binding met de arbeids } \\
\text { markt (bijv. scholieren) }\end{array}$ & $\begin{array}{l}\text {-flexibele, onaan- } \\
\text { trekkelijke functies } \\
\text {-kleine bedrijven zonder } \\
\text { stabiele afzetmarkt }\end{array}$ & $\begin{array}{l}\text {-externe mobiliteit } \\
\text {-voor bep. groepen } \\
\text { 'voorportaal' van de } \\
\text { interne arbeidsmarkt }\end{array}$ \\
\hline
\end{tabular}

Bron: Dekker c.s., 1995

De secundaire arbeidsmarkt heeft betrekking op flexibele functies die qua arbeidsomstandigheden onaantrekkelijk zijn, waarvoor geen vakspecifieke of bedrijfsspecifieke vaardigheden vereist zijn. Dergelijke functies zijn vaak te vinden bij kleine ondernemingen waarvoor een stabiele afzetmarkt ontbreekt. De mobiliteitsmogelijkheden zijn hier meestal extern. Wel is voor bepaalde groepen (bijvoorbeeld jongeren) de secundaire arbeidsmarkt het 'voorportaal' van de interne arbeidsmarkt (Treu, 1992). Jongeren stromen vaak in via het secundaire gedeelte van de arbeidsmarkt, werken daar een bepaalde periode en stromen vervolgens door naar de interne arbeidsmarkt. 


\section{Effecten van scholing}

De opbrengst van scholing voor werknemers wordt vaak gemeten in termen van inkomenseffecten. Op basis van een vergelijking van een aantal studies op dit punt komt Groot (1998) tot de conclusie dat de inkomenseffecten van scholing vrij groot zijn maar dat de verschillende onderzoeken wel sterk uiteenlopende resultaten laten zien. Sicherman (1990) komt overigens tot de conclusie dat voor hoog opgeleiden de inkomenseffecten van scholing kleiner zijn, omdat er voor deze groep een 'tradeoff' bestaat tussen directe inkomensverbeteringen en de latere kans op opwaartse mobiliteit die bepaalde functies kunnen bieden.

Uit het onderzoek van Sicherman (1990) blijkt verder dat het niveau van de initiële opleiding een negatief effect heeft op de mobiliteit van werkenden. Wanneer er echter rekening gehouden wordt met het beroep waarin men werkzaam is, blijken hoog opgeleiden juist mobieler te zijn dan lager opgeleiden. In Dekker c.s. (1995) komt de invloed van bedrijfsscholing op de mobiliteit aan de orde, waarbij er rekening wordt gehouden met de drie eerder genoemde segmenten op de arbeidsmarkt en waarbij onderscheid wordt gemaakt tussen 'core-training' en 'career training'. De eerste vorm van bedrijfsscholing is erop gericht de benodigde competenties voor de huidige baan op peil te houden. 'Career training' is scholing die loopbaangericht is. Uit de resultaten van het onderzoek van Dekker c.s. blijkt dat scholing die gericht is op het tegengaan van kwalificatieveroudering ('core-training') zowel de interne als ook de externe mobilititeit niet significant beïnvloedt.

Om de mogelijke effecten van scholing die gericht is op het tegengaan van kwalificatieveroudering in kaart te brengen, wordt in tabel 2.3 een overzicht gegeven van de mogelijke effecten van het vergroten van de zes soorten competenties zoals die eerder in het hoofdstuk aan de orde kwamen. Het overzicht, dat gebaseerd is op de voorbeeld-competenties uit tabel 2.1, moet gezien worden als illustratief.

In tabel 2.3 wordt er van elk van de zes onderscheiden competenties die door de scholing kunnen worden verworven, een voorbeeld gegeven en aangegeven wat het effect is dat een dergelijke scholing op een bepaald arbeidsmarktsegment kan hebben op de inkomensontwikkeling, de loopbaanmogelijkheden en het tegengaan van kwalificatie-veroudering.

Scholing die gericht is op het tegengaan van kwalificatieveroudering kan zowel een preventief als een curatief karakter hebben. In het eerste geval gaat scholing de mogelijke kwalificatieveroudering vooraf, in het tweede geval is scholing een reactie op al opgetreden kwalificatieveroudering. Om de vormen van kwalificatieveroudering, die met het aanleren van bepaalde soorten competenties kunnen worden tegengegaan, te kunnen identificeren maakt het nogal een verschil of het gaat om preventieve of curatieve scholing. 


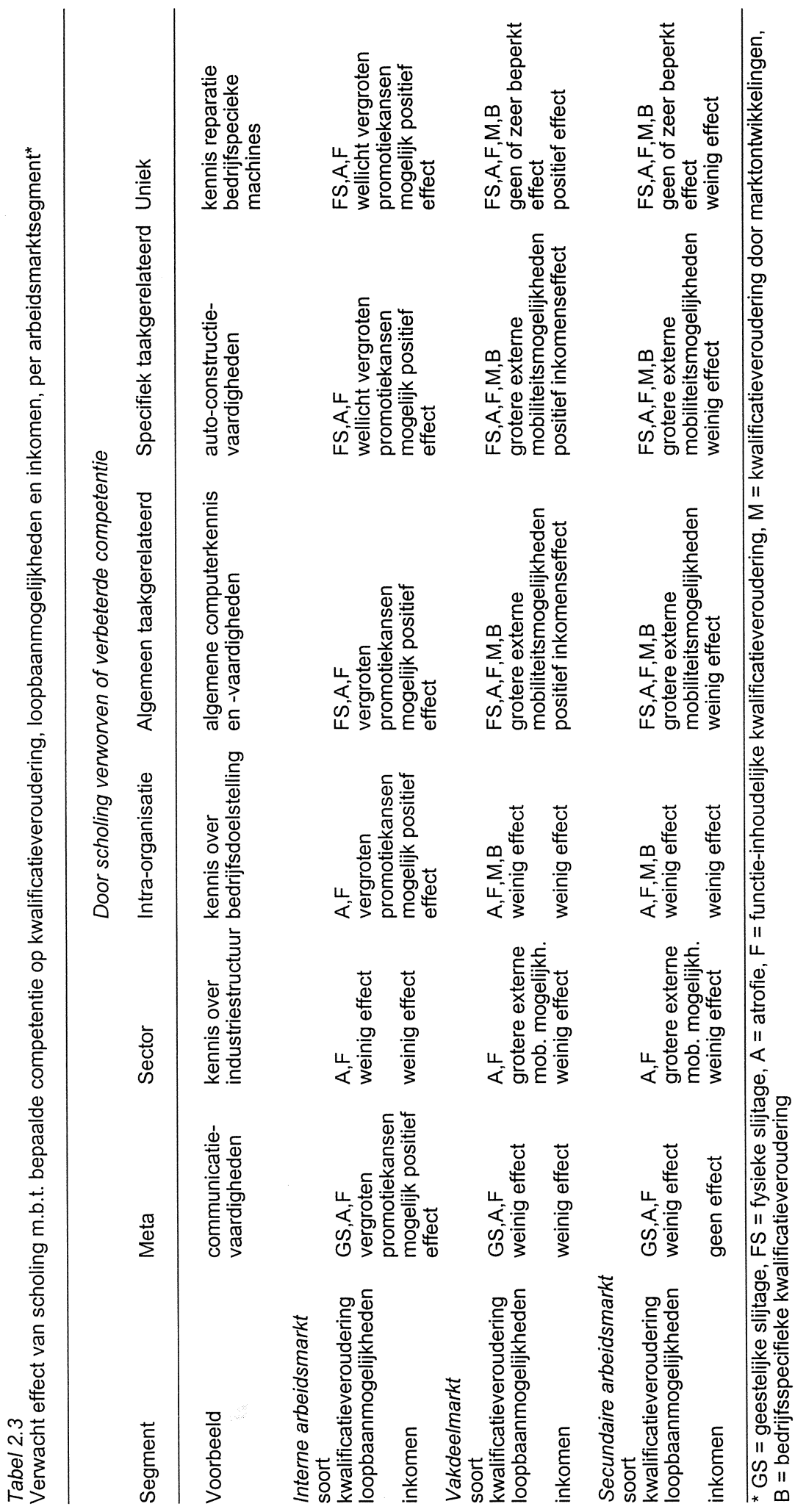


Zo is atrofie (het verliezen van competenties doordat ze een tijd niet gebruikt worden) wellicht te voorkomen door te investeren in scholing die meta-competenties verbetert of aanleert. Daarbij zou gedacht kunnen worden aan competenties die het vermogen om bepaalde 'skills' langer productief te kunnen aanwenden, verbeteren. Wanneer atrofie er voor heeft gezorgd dat bepaalde competenties verloren zijn gegaan, is de zaak anders. Zo is bijvoorbeeld scholing die gericht is op het verwerven van (verloren gegane) algemeen taakgerelateerde competenties, een manier om de al opgetreden atrofie tegen te gaan.

In tabel 2.3 wordt alleen aandacht besteed aan scholing die curatief ingezet wordt, en die dus gericht is op het tegengaan van kwalificatieveroudering die zich reeds manifesteert. Bij de invulling van tabel 2.3 kan slechts in beperkte mate gebruik worden gemaakt van de bestaande literatuur, aangezien het onderzoek dat zich richt op de effecten van scholing, die specifiek gericht is op het tegengaan van kwalificatieveroudering en dat tegelijkertijd rekening houdt met de competenties die worden aangeleerd en de mobiliteitsmogelijkheden van werknemers, erg schaars is. $\mathrm{Er}$ is daarentegen wel onderzoek gedaan naar de effecten van scholing op inkomen en mobiliteit in het algemeen, waarbij scholing niet noodzakelijkerwijs geïnitieerd wordt om kwalificatieveroudering te voorkomen en de mobiliteitsmogelijkheden en de aard van de aangeleerde competenties meestal geen rol spelen.

Atrofie en functie-inhoudelijke kwalificatieveroudering kunnen betrekking hebben op alle soorten competenties en kunnen daarom worden tegengegaan door scholing die tot gevolg heeft dat de benodigde competenties aangeleerd worden. Vandaar dat atrofie $(A)$ en functie-inhoudelijke kwalificatieveroudering $(F)$ in elk van de afzonderlijke cellen van tabel 2.3 voorkomen.

Slijtage kan zowel geestelijk als fysiek van aard zijn. Wanneer een werknemer te maken heeft met geestelijke slijtage (GS) ligt het volgen van scholing die gericht is op de verwerving van meta-competenties het meest voor de hand. Stress kan bijvoorbeeld worden tegengegaan door het volgen van een cursus time-management. Fysieke slijtage (FS) is normaal gesproken gerelateerd aan de kenmerken van het beroep en daarom kan scholing die algemeen taakgerelateerde, specifiek taakgerelateerde of unieke competenties aanleert, worden ingezet om fysieke slijtage tegen te gaan. Daarbij kan bijvoorbeeld gedacht worden aan het beter gebruiken van apparatuur, zodat men minder last heeft van de fysieke slijtage die met het werk gepaard gaat. Een andere, zeer voor de hand liggende oplossing, het verminderen van slijtage door het veranderen van de werkzaamheden, komt hier niet aan de orde. Het gaat immers om de rol die scholing kan spelen bij het voorkomen van kwalificatieveroudering.

Kwalificatieveroudering kan ook optreden als gevolg van marktontwikkelingen (M) en bedrijfswisselingen $(B)$. In het eerste geval is er sprake van krimpende werkge- 
legenheid in het beroep of de sector waar men werkzaam is. Bij bedrijfsspecifieke kwalificatieveroudering gaat (bedrijfsspecifiek) menselijk kapitaal verloren doordat werknemers gedwongen zijn van bedrijf te wisselen. Op de interne arbeidsmarkt zijn beide vormen van kwalificatieveroudering weinig relevant. Het gaat hier namelijk meestal om werknemers die vaste arbeidscontracten hebben en waarbij de mobiliteit overwegend intern gericht is. In de andere onderscheiden arbeidsmarktsegmenten (de vakdeelmarkt en de secundaire arbeidsmarkt) kan scholing die kwalificatieveroudering door marktontwikkelingen of bedrijfsspecifieke kwalificatieveroudering wel een belangrijke rol spelen. Dit geldt echter waarschijnlijk niet in dezelfde mate voor alle onderscheiden competenties. Scholing is bijvoorbeeld minder van belang bij het weer op peil brengen van meta- en sector competenties, aangezien deze door marktontwikkelingen of bedrijfswisselingen, gezien het algemene karakter van deze competenties, waarschijnlijk niet direct beïnvloed worden.

\subsection{De betekenis van scholing voor bedrijven}

De betekenis voor bedrijven van scholing die kwalificatieveroudering tegengaat kan vanuit een aantal invalshoeken bekeken worden. Allereerst kan de nadruk worden gelegd op de invloed van scholing op het productieproces. Daarnaast kan de invloed van scholing op de bedrijfsprestaties bekeken worden.

\section{Scholing en het productieproces}

Cörvers (1994) onderscheidt vier manieren waarop vaardigheden van werknemers aan het productieproces van bedrijven bijdragen. Het gaat achtereenvolgens om

- het werknemer-effect;

- het allocatie-effect;

- het diffusie-effect;

- het research-effect.

Scholing in bedrijven heeft ten doel de vaardigheden van werknemers te vergroten of op peil te houden om zo kwalificatieveroudering tegen te gaan. De toename van de bij werknemers beschikbare vaardigheden zal daarnaast één of meerdere van de vier genoemde effecten hebben. In het volgende worden deze effecten kort toegelicht:

Het werknemer-effect komt voort uit het feit dat werknemers met meer en/of betere vaardigheden bepaalde taken beter kunnen blijven uitvoeren. Het werknemer-effect van scholing is groter naarmate het bedrijf complexer is op het gebied van productieproces of organisatie. 
Het allocatie-effect is een gevolg van het feit dat werknemers met vaardigheden die voldoende op peil zijn een grotere allocatieve efficientie kunnen bereiken. Dat wil zeggen dat ze de productiemiddelen op een betere manier met elkaar kunnen combineren. Daarnaast kunnen de vaardigheden, naast de allocatieve efficientie van de werknemer zelf, de productiviteit van een grotere groep werknemers vergroten. Bij de scholing van managers, bijvoorbeeld, zullen de allocatieve effecten niet beperkt blijven tot hun eigen activiteiten. Ook bij hun ondergeschikten kunnen productiviteitsverbeteringen optreden als gevolg van het allocatie-effect.

Wanneer werknemers doordat hun vaardigheden voldoende op peil zijn beter en sneller in staat zijn om bepaalde technologische vernieuwingen door te voeren, dan is er sprake van een diffusie-effect. De achtergrond hiervan is dat een hoger vaardigheden-niveau het vermogen om te beoordelen welke innovaties (op technologisch, maar ook op organisatorisch gebied) het meest winstgevend zijn, vergroot.

Het laatste effect is het research-effect. Het gaat hier om de vaardigheden die een input vormen voor de R\&D-activiteiten. Uit moderne groeitheorie-literatuur (zie bijvoorbeeld Barro en Sala-I-Martin, 1995) blijkt dat deze activiteiten sterk bepalend zijn voor de technologische vooruitgang en de mate van economische groei.

Uit de analyses van Bartel (1991) blijkt dat de productiviteit in bedrijven duidelijk beïnvloed wordt door de mate waarin bedrijven scholing aanbieden. Uit de resultaten van dit onderzoek komt naar voren dat ondernemingen die een lager dan gemiddelde productiviteit hebben en investeren in nieuwe scholingsprogramma's voor hun werknemers significant hogere productiviteitsstijgingen hebben dan vergelijkbare bedrijven die geen nieuwe scholingsactiviteiten ontplooien.

\section{Scholing en bedrijfsprestaties}

De productiviteitseffecten van scholing met als doel het tegengaan van kwalificatieveroudering hebben ook invloed op de bedrijfsprestaties. Bedrijfsprestaties kunnen zowel de continuïteit als de financiële bedrijfsprestaties omvatten. Uit onderzoek (Bentlage c.s., 1989) blijkt dat, in Nederland, bedrijfsscholing beide soorten bedrijfsprestaties beïnvloedt. De factoren die de meeste invloed op de bedrijfsprestatie hebben, zijn: de positionering van de opleidingsfunctie binnen het bedrijf, de wijze waarop de informatie over kwalificaties van werknemers en functies gebruikt wordt bij het opleiden en selecteren van werknemers en de hoeveelheid opleidingen per werknemer per jaar. Uit het onderzoek komt verder naar voren dat kort en goedkoop, maar wel regelmatig opleiden het meest bijdraagt aan de bedrijfsprestatie. 


\subsection{Samenvatting en conclusie}

In dit hoofdstuk is aandacht geschonken aan scholing die tot doel heeft kwalificatieveroudering tegen te gaan. Allereerst is er ingegaan op de vraag waarom werknemers en bedrijven juist door middel van scholing de met kwalificatieveroudering gepaarde problemen te lijf te kunnen gaan.

Werknemers hebben in principe drie opties om met kwalificatieveroudering om te gaan. Ze kunnen veranderen van baan, de arbeidsmarkt verlaten of investeren in hun eigen kennis en vaardigheden om hun kwalificaties op peil te houden. De eerste mogelijkheid is gegeven de reikwijdte van maatschappelijke ontwikkelingen (zoals bijvoorbeeld de in alle sectoren voortschrijdende informatisering), slechts voor weinig werknemers een reële optie. De arbeidsmarkt verlaten is alleen voor werknemers die gebruik kunnen maken van specifieke uittredingsfaciliteiten (V.U.T.regelingen, e.d.) aanvaardbaar. Voor de meeste andere werknemers is de met uittrede gepaard gaande inkomensdaling echter onaanvaardbaar. De derde optie wordt daardoor steeds belangrijker: het volgen van scholing wordt het belangrijkste instrument om de kwalificatieveroudering die het gevolg is van de verschillende ontwikkelingen die op werknemers afkomen, te lijf te gaan.

Bedrijven kunnen de problemen die optreden als gevolg van kwalificatieveroudering bij hun personeel ook op verschillende manieren oplossen. Zo zou een bedrijf bijvoorbeeld werknemers voor een beperkte tijd kunnen aannemen en ze weer ontslaan wanneer hun kwalificaties tekort beginnen te schieten. Deze optie wordt echter steeds moeilijker in de praktijk uit te voeren gezien de demografische tendensen (ontgroening en vergrijzing) in de beroepsbevolking en het feit dat de snelle technologische en organisatorische ontwikkelingen ervoor zorgen dat werknemers zonder aanvullende scholing nog maar een korte periode voldoende productief zijn. Al met al nopen deze ontwikkelingen bedrijven ertoe, zich te richten op het investeren in het menselijk kapitaal van hun medewerkers.

Vervolgens is er gekeken naar de betekenis van scholing die gericht is op het tegengaan van kwalificatieveroudering, wederom voor zowel werknemers als bedrijven. Voor werknemers heeft dergelijke scholing drie mogelijke effecten: het voorkomen van kwalificatieveroudering, loopbaaneffecten en inkomenseffecten.

De mogelijke effecten worden gerelateerd aan twee factoren. Enerzijds vormt de breedte van de door een opgeleide aangeleerde competentie een belangrijke invloedsfactor. Anderzijds zijn de mobiliteitsmogelijkheden van werknemers van belang. In tabel 2.3 worden de effecten van scholing die gericht is op het voorkomen van kwalificatieveroudering gerelateerd aan deze twee factoren. 
De effecten van kwalificatieveroudering-verminderende scholing voor bedrijven kan zowel bekeken worden door te kijken naar de invloed op het productieproces als naar de bedrijfsprestaties. Uit onderzoek blijkt dat zowel de productiviteit als ook de bedrijfsprestaties positief samenhangen met de scholingsintensiteit. 


\section{Risicofactoren en kwalificatieveroudering}

\subsection{Inleiding}

In dit hoofdstuk wordt een belangrijke veronderstelling uit het WSO instrumentarium getoetst. Het gaat er om te onderzoeken in hoeverre de veronderstelde relaties tussen enerzijds de risicofactoren waarmee werknemers geconfronteerd worden en de scholingsinspanningen en de employability en de diverse vormen van kwalificatie-veroudering anderzijds, opgaan. In feite is dit de centrale vraagstelling binnen de WSO-thematiek (zie ROA, 1998a/b). Er zal getracht worden risico-indicatoren zoals arbeidsomstandigheden, technologische en organisatorische ontwikkelingen en arbeidsmarktontwikkelingen te relateren aan de diverse vormen voor kwalificatieveroudering. Met behulp van analyses op het niveau van de individuele werknemer zal bekeken worden in hoeverre risicofactoren daadwerkelijk kwalificatie-veroudering in de hand werken en in hoeverre scholing en employability dat tegen kunnen gaan.

\section{Vormen van kwalificatieveroudering}

Het centrale idee in dit hoofdstuk is dat de in het WSO onderscheiden vormen (zie ROA, 1998a/b) van kwalificatieveroudering zoveel mogelijk apart aan de orde zullen komen. Tabel 3.1 geeft voor iedere vorm van kwalificatieveroudering een korte definitie en geeft aan waar ze in dit hoofdstuk aan de orde zullen komen.

Tabel 3.1

Vormen van kwalificatieveroudering en opbouw van het hoofdstuk

\begin{tabular}{llc}
\hline Soort kwalificatieveroudering & Afschrijving menselijk kapitaal door: & Paragraaf \\
\hline Slijtage & $\begin{array}{l}\text { Natuurlijk ouderwordingsproces, } \\
\text { ziekte of letsel }\end{array}$ & 3.2 \\
Atrofie & $\begin{array}{l}\text { Niet of onvoldoende gebruiken van } \\
\text { kwalificaties }\end{array}$ & 3.3 \\
$\begin{array}{l}\text { Functie-inhoudelijke } \\
\text { kwalificatieveroudering }\end{array}$ & $\begin{array}{l}\text { Nieuwe kwalificatievereisten voor } \\
\text { de functie }\end{array}$ & 3.4 \\
$\begin{array}{l}\text { Kwalificatieveroudering door } \\
\text { marktontwikkelingen }\end{array}$ & $\begin{array}{l}\text { Krimpende werkgelegenheid in } \\
\text { bepaald beroep of bedrijfssector }\end{array}$ & 3.5 \\
$\begin{array}{l}\text { Bedrijfspecifieke } \\
\text { kwalificatieveroudering }\end{array}$ & $\begin{array}{l}\text { Externe mobiliteit } \\
\text { Bron: ROA, }\end{array}$ & 3.5 \\
\hline
\end{tabular}

Bron: ROA, 1998

Het apart benaderen van de diverse vormen van kwalificatieveroudering heeft als voordeel dat de oorzaken en de gevolgen van kwalificatieveroudering op een op de specifieke problematiek toegespitste wijze onderzocht kunnen worden. Het is wel mogelijk dat sommige vormen van kwalificatieveroudering door het ontbreken van 
bepaalde essentiële variabelen in de gebruikte databestanden niet of minder goed onderzocht kunnen worden.

In dit hoofdstuk worden de resultaten van de analyses schematisch weergegeven. De volledige statistische resultaten zijn te vinden in de bijlage achterin dit rapport.

\section{Factoren die kwalificatieveroudering tegengaan}

In de analyses van dit hoofdstuk worden telkens naast de risico-factoren die kwalificatieveroudering in de hand kunnen werken ook variabelen opgenomen waarvan in het WSO-model verondersteld wordt dat ze kwalificatieveroudering kunnen tegengaan of voorkomen. Het gaat hier om een zestal indicatoren, die zowel scholingsals employability-aspecten omvatten. Een overzicht van deze indicatoren wordt gepresenteerd in tabel $3.2^{3}$.

In een aantal analyses is daarnaast gebruik gemaakt van andere indicatoren. Zo wordt er bij de analyse van kwalificatieveroudering door marktontwikkelingen en bedrijfsspecifieke kwalificatieveroudering bijvoorbeeld gebruik gemaakt van het aantal cursussen dat in de twee voorafgaande jaren is gevolgd. Waar andere indicatoren dan de in tabel 3.2 genoemde indicatoren gebruikt worden, wordt daarop bij de desbetreffende analyse apart ingegaan.

\section{Gebruikte data}

Bij de analyses in dit hoofdstuk wordt gebruik gemaakt van de OSA-arbeidsaanbodsurveys van 1994 en 1996. Dit OSA-survey is een enquête die bij een steekproef van de bevolking tussen 16 en 65 jaar is afgenomen. In de analyses zullen de diverse vormen van kwalificatieveroudering daarom op individueel niveau worden geanalyseerd. Daarbij gaat het, zoals gezegd, ook om het traceren van de mate waarin de risicofactoren waarmee werknemers geconfronteerd worden daadwer-

3. Een uitvoerige beschrijving en onderbouwing van deze indicatoren is te vinden in A. de Grip C.s. (1998), Employability in bedrijf: Naar een Employability Index voor Bedrijfssectoren, ROAR-1998/10. Overigens verschillen de in dit rapport ontwikkelde indicatoren, met uitzondering van de bereidheid tot brede inzetbaarheid, van de indicatoren die in het vorige WSOoverzichtsrapport gebruikt zijn. De scholingsvariabele die in dat WSO rapport gebruikt is, is afkomstig uit de Enquête Beroepsbevolking van het CBS, en is daarom niet direct vergelijkbaar met de scholingsvariabelen die in dit hoofdstuk gebruikt worden. De CBS-gegevens laten toe om de scholingsbehoefte voor een groot aantal bedrijfssectoren, beroepsgroepen en opleidingstypen in kaart te kunnen brengen. Dit is met de beperkte omvang van het OSAarbeidsaanbodsurvey niet mogelijk. Maar omdat de analyses in dit hoofdstuk niet gericht zijn op groepen werkenden, maar op de individuele werknemer, ligt het hier meer voor de hand om de OSA-gegevens over scholing op individueel niveau te gebruiken. 
kelijk tot kwalificatieveroudering leiden. De gevolgen van kwalificatieveroudering voor bedrijven komen dus niet aan de orde.

Tabel 3.2

Factoren die kwalificatieveroudering tegengaan of voorkomen

\begin{tabular}{ll} 
Factoren & Indicatoren \\
\hline Mobiliteitsbereidheid & $\begin{array}{l}\text { Zoekgedrag } 12 \text { maanden voorafgaand aan enquête. Het } \\
\text { gaat om het zoeken van een andere hoofdbaan op initiatief } \\
\text { van de werknemer zelf. }\end{array}$ \\
Mobiliteitsvermogen & $\begin{array}{l}\text { De verhouding tussen de verblijfsduur in de huidige functie } \\
\text { en de totale verblijsduur op de arbeidsmarkt, gecorrigeerd } \\
\text { voor de leeftijd van de werknemer. }\end{array}$ \\
Opleidingsbereidheid & $\begin{array}{l}\text { De mate waarin werknemers opleidingen volgen, bepaald } \\
\text { aan de hand van het aantal opleidingen, financiële en tijds- } \\
\text { aspecten. }\end{array}$ \\
Opleidingsvermogen & $\begin{array}{l}\text { De totale tijd dat een werknemer in opleiding is geweest; } \\
\text { daarbij gaat het zowel om de initiële opleiding als om de } \\
\text { later gevolgde opleidingen en cursussen. }\end{array}$ \\
$\begin{array}{l}\text { Bereidheid tot brede } \\
\text { inzetbaarheid }\end{array}$ & $\begin{array}{l}\text { Bereidheid tot het vervullen van werkzaamheden die } \\
\text { eigenlijk niet tot de eigen functie behoren. }\end{array}$ \\
Vermogen tot brede \\
inzetbaarheid
\end{tabular}

Bron: De Grip c.s., 1998

Er is een aantal voorselecties gemaakt. Zo worden er bijvoorbeeld alleen werknemers in de analyse meegenomen; zelfstandigen blijven buiten beschouwing. Verder worden in de analyses waarbij meerdere enquêtes (1994 en 1996) worden gebruikt, alleen personen die aan beide enquêtes hebben meegewerkt, in het databestand opgenomen.

\subsection{Slijtage}

Slijtage wordt gedefinieerd als de afschrijving van menselijk kapitaal door het natuurlijk ouderwordingsproces, ziekte, of letsel. De gevolgen kunnen zowel economisch als sociaal van aard zijn (De Koning c.s., 1996). Arbeidsomstandigheden kunnen een belangrijke invloed hebben op de slijtage van werknemers. Daarnaast kunnen ze de resultaten van bedrijven beïnvloeden. Daarbij kan gedacht worden aan negatieve productiviteitseffecten, ontslagkosten en kosten van werving en training van nieuwkomers. Slijtage zal hier benaderd worden als oorzaak van kwalificatie- 
veroudering. In de analyse zullen de mogelijke oorzaken van slijtage gerelateerd worden aan het optreden ervan.

\section{Het meten van slijtage}

De slijtage bij werknemers zou idealiter moeten worden gemeten door te kijken naar veranderingen in de fysieke en psychische capaciteiten van werknemers. Dat is echter in de praktijk erg moeilijk. Het is vaak wel mogelijk gevolgen van slijtage te meten. Die gevolgen kunnen zich op een aantal manieren manifesteren. Daarbij kan gedacht worden aan:

- arbeidsongeschiktheid;

- arbeidsgerelateerd ziekteverlof;

- vertrek naar andere functies (Chelius, 1974).

Arbeidsongeschiktheid kent twee mogelijke oorzaken. Allereerst kan er sprake zijn van een lange periode van sterk belastende arbeidsomstandigheden. Daarnaast kan een werknemer een (al dan niet werkgerelateerd) ongeval hebben. Arbeidsongeschiktheid is daarmee het ultieme gevolg van slijtage of het gevolg van een noodlottig incident. Aangezien de verklaring van slijtage alleen gezocht kan worden in belastende arbeidsomstandigheden en de oorzaak van iemands arbeidsongeschiktheid (langdurige blootstelling aan belastende omstandigheden, noodlottig incident of niet-werkgerelateerde oorzaken) in het databestand niet te achterhalen is, is het niet verstandig arbeidsongeschikten in de analyse op te nemen. Arbeidsongeschiktheid kan namelijk ook door een niet-werkgerelateerd noodlottig incident veroorzaakt worden en in dit geval hebben de arbeidsomstandigheden geen directe invloed. Arbeidsgerelateerd ziekteverlof is waarschijnlijk een betere maatstaf voor het optreden van slijtage. Weliswaar is arbeidsgerelateerd ziekteverlof ook een gevolg van slijtage, maar deze indicator kan beter gerelateerd worden aan de oorzaken ervan (belastende arbeidsomstandigheden). Wanneer een werknemer langere tijd met werkgerelateerd ziekteverlof is, is dat een indicatie van het bestaan van slijtage. Deze slijtage kan lichamelijk van aard zijn, maar ook geestelijk ('burn-out').

Ook het vertrek naar een andere functie kan een gevolg van slijtage zijn. Als een werknemer een aantal jaren onder belastende omstandigheden gewerkt heeft, kan het wisselen van baan arbeidsongeschiktheid wellicht voorkomen. Echter, het wisselen van baan heeft vaak heel andere oorzaken. Het kan bijvoorbeeld ook het gevolg zijn van persoonlijke omstandigheden, betere loopbaanperspectieven of ontslag. Slijtage is daarmee slechts een beperkte invloedsfactor, wat impliceert dat baanwisselingen als indicator van slijtage ongeschikt zijn.

Aangezien het doel van deze paragraaf is de slijtage bij werknemers te relateren aan de huidige arbeidsomstandigheden waarmee men geconfronteerd wordt, is het 
voor de analyse het verstandigst om het langdurig werkgerelateerd ziekteverlof als indicator van het optreden van slijtage te nemen. Hieronder wordt verstaan werkgerelateerd ziekteverlof van twee weken of langer.

Het meten van factoren die slijtage beïnvloeden

De factoren die slijtage beïnvloeden zijn ruwweg te verdelen in persoonskenmerken, omgevingsfactoren en activiteiten van werknemers en bedrijven die er op gericht zijn de slijtage of de invloed ervan te verminderen. Voorbeelden van persoonskenmerken zijn geslacht en leeftijd. Omgevingsfactoren zijn kenmerken van de baan, het bedrijf en de bedrijfssector waarin de werknemer werkzaam is. Een voorbeeld van activiteiten die slijtage of de invloed ervan beogen te verminderen is het volgen van cursussen die werknemers aanleren hun werk zodanig in te richten of uit te voeren dat belastingsfactoren minder invloed hebben en/of de veiligheid bij het uitvoeren van de werkzaamheden vergroten.

\section{De relatie tussen belastingsfactoren en slijtage}

De invloed van bepaalde persoonskenmerken, omgevingsfactoren en activiteiten gericht op het verminderen van de slijtage wordt onderzocht door gebruik te maken van een zogenaamd binomiaal logit model. In zo'n model wordt de kans op langdurig werkgerelateerd ziekteverlof gerelateerd aan een aantal verklarende variabelen.

Figuur 3.1

De relatie tussen slijtage-oorzaken, risico-verhogende en risico-verlagende factoren

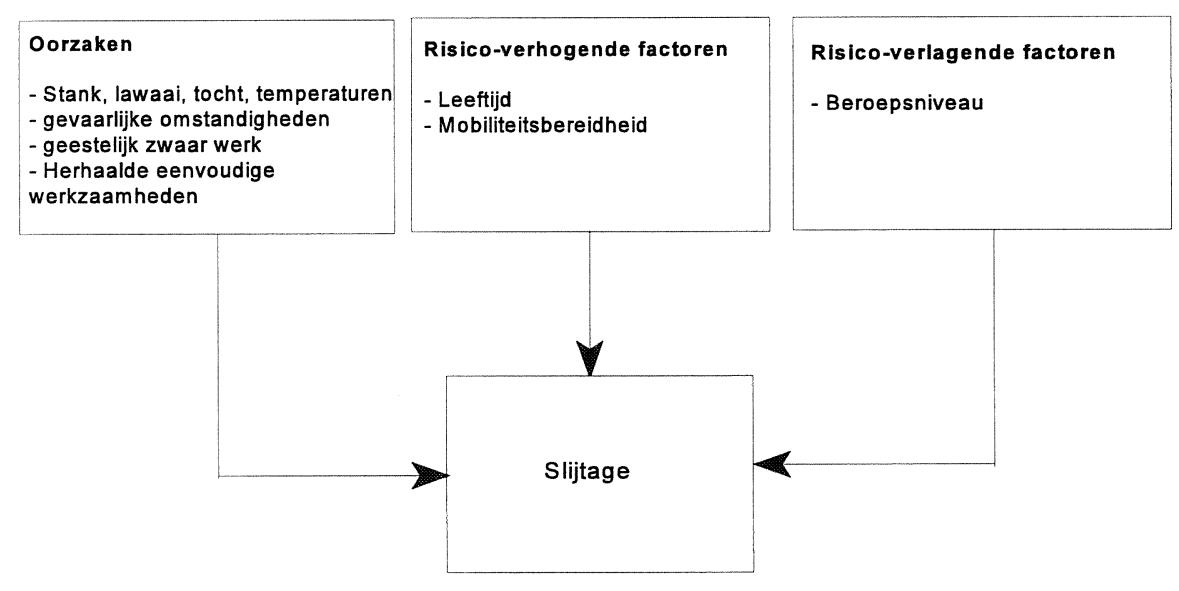


Om het model te schatten is de volgende aanpak gevolgd. In eerste instantie zijn alle mogelijk relevante verklarende variabelen in het model opgenomen. Op basis van een correlatie-analyse is er daarna een aantal arbeidsomstandigheden-variabelen uit het model geschrapt. Vervolgens zijn er stapsgewijs andere variabelen uit het model gehaald. Daarbij is gekeken naar de significantie van de variabele en het teken ervan. De uiteindelijke resultaten van de analyse worden schematisch gepresenteerd in figuur 3.1. De statistische resultaten zijn te vinden in tabel B1 in de bijlage achterin dit rapport.

Uit de analyse blijkt dat de leeftijd van een werknemer een positief effect heeft op de kans op werkgerelateerd ziekteverlof. Oudere werknemers hebben daar dus een grotere kans op. Verder lijkt het dat vrouwen een (niet-significant) hogere kans hebben op een dergelijk ziekteverlof dan mannen. Dit effect, dat op het eerste gezicht implausibel zou kunnen lijken, wordt waarschijnlijk mede veroorzaakt doordat de in het model opgenomen belastingsfactoren corrigerend werken. Voor de meeste belastingsfactoren geldt namelijk dat de mannelijke werknemers er in de werksituatie vaker mee te maken krijgen (zie ook Kunnen c.s., 1997).

Om de invloed van de belastende arbeidsomstandigheden in de werksituatie op de kans op langdurig ziekteverlof te onderzoeken, zijn, zoals gezegd, in eerste instantie alle beschikbare arbeidsomstandigheden-variabelen in het model opgenomen. Maar omdat er vaak sprake is van het tegelijkertijd optreden van een aantal belastingsfactoren (bijvoorbeeld: 'werken met een lopende band' impliceert vaak 'herhaling van dezelfde eenvoudige werkzaamheden') is er sprake van sterk samenhangende variabelen, waardoor de schatting van het model niet goed mogelijk is (multicollineariteit). Vandaar dat er een aantal belastingsfactoren uit het model is geschrapt.

Van de belastingsfactoren die wel in het model zijn opgenomen wordt verwacht dat ze de kans op een werkgelelateerd ziekteverlof van twee weken of meer positief beïnvloeden. Dat blijkt zowel het geval te zijn bij de fysiek belastende arbeidsomstandigheden (stank, lawaai, tocht, lage/hoge temperaturen, gevaarlijke omstandigheden) als bij de psychische belasting (geestelijk zwaar werk). Wat verder opvalt, is dat het effect van het hebben van een baan waarin veelal dezelfde eenvoudige werkzaamheden verricht moeten worden groot is. Dit soort werkzaamheden (lopende-band-werk, etc.) heeft van alle belastingsfactoren zelfs het grootste effect. De enige belastingsfactor die de kans op langdurig ziekteverlof lijkt te verkleinen, is het hebben van een flexibel jaarrooster. Dit resultaat moet voorzichtig geïnterpreteerd worden. Allereerst is dit effect niet erg significant. Bovendien kan flexibiliteit twee effecten hebben op de kans op ziekteverlof. Wanneer het inhoudt dat een werknemer de flexibiliteit opgedrongen wordt, waardoor hij op erg wisselende tijden moet werken, dan kan het zijn dat dit de kans op ziekteverlof vergroot. Als werknemers daarentegen zelf een zekere vrijheid hebben in het kiezen van hun werktijden, dan kan flexibiliteit inhouden dat men de vrijheid heeft om de eigen werktijd in te delen, 
waardoor de kans op langdurig ziekteverlof afneemt (zie ook Nijhuis, 1995). Dit laatste effect speelt hier blijkbaar de grootste rol.

De activiteiten die gericht zijn op het verminderen van de slijtage zouden volgens het WSO-model (ROA, 1998) kwaliteitsveroudering moeten tegengaan. Daarom zijn er ook variabelen die de scholingsinspanning en de employability van de werknemer indiceren in de analyse opgenomen. Het blijkt echter dat geen van deze variabelen een significant negatief effect op de kans op langdurig ziekteverlof heeft. De enige variabele die wel een significante invloed heeft, is de mobiliteitsbereidheid van werknemers. Een hoge mobiliteitsbereidheid blijkt echter gepaard te gaan met een grotere kans op slijtage. Hier speelt echter waarschijnlijk mee dat mensen die aangeven op zoek te zijn naar een andere baan, dat ook vaak doen omdat ze de huidige werksituatie niet goed meer aankunnen. In dat geval is de variabele niet meer een echte employability-variabele, maar een indicatie van de wens om van baan te wisselen vanwege de slijtage waarmee men kampt, of vanuit een meer algemene onvrede met de functie die men uitoefent.

\subsection{Atrofie}

Atrofie is kwalificatieveroudering die ontstaat doordat bepaalde kennis en vaardigheden niet of onvoldoende gebruikt worden. Om atrofie op een verantwoorde wijze te meten, zouden de beschikbare vaardigheden van individuele werknemers op meerdere momenten gemeten moeten worden. Ook zou het gebruik van die vaardigheden in de werksituatie of elders tussen de enquêtemomenten bevraagd moeten worden. Aangezien deze informatie in de beschikbare databronnen niet aanwezig is, kan het optreden van atrofie niet gerelateerd worden aan bepaalde risicofactoren. Wanneer er, zoals bijvoorbeeld in het Verenigd Koninkrijk (zie bijvoorbeeld (Green c.s., 1997)) nieuwe databestanden, die competentie-ontwikkeling als centrale invalshoek hebben, beschikbaar zouden komen, zal dit wellicht wel mogelijk zijn.

\subsection{Functie-inhoudelijke kwalificatieveroudering}

Wanneer de inhoud van een functie onderhevig is aan verandering, kunnen de kwalificatievereisten voor die functie veranderen. Indien de kwalificatievereisten dusdanig veranderen dat de bestaande kennis en vaardigheden niet langer toereikend zijn voor een adequate functievervulling, is er sprake van functie-inhoudelijke kwalificatieveroudering. Soms leiden veranderde kwalificatievereisten er zelfs toe dat bij de werving van personeel een andere opleidingsrichting wordt gevraagd dan in het verleden. Daarnaast is het mogelijk dat werkgevers vanwege technologische of organisatorische ontwikkelingen voor bepaalde functies een hoger opleidingsniveau eisen. In dat geval is er sprake van 'upgrading' van het functieniveau. Op een macro-niveau kan upgrading ook tot uiting komen in een veranderende beroe- 
penstructuur; in dat geval wordt het aandeel van werkenden in de lagere en elementaire beroepen kleiner en het aandeel van werkenden in hogere beroepen groter (De Grip en Hoevenberg, 1996).

Werknemers met een opleiding die niet aansluit bij de nieuwe kwalificatie-eisen, worden geconfronteerd met functie-inhoudelijke kwalificatieveroudering. Naarmate de veranderingen van de functie-inhoud zich sneller voordoen, en de discrepantie tussen de vereiste en beschikbare kwalificaties dus steeds groter wordt, zal de kwalificatieveroudering ernstiger zijn.

Het meten van functie-inhoudelijke kwalificatieveroudering

De ideale manier om deze vorm van kwalificatieveroudering te meten, is een vergelijking op verschillende tijdstippen van de kwalificatievereisten voor een bepaalde functie en de kwalificaties waarover werknemers in die functie beschikken. Helaas is dat met de beschikbare databronnen niet mogelijk.

Om de kwalificatieveroudering toch te kunnen meten, is gebruik gemaakt van een vraag die betrekking heeft op veroudering van de opleiding doordat het werk anders is geworden. De respondenten die hierop bevestigend antwoorden, worden aangemerkt als 'slachtoffer' van functie-inhoudelijke kwalificatieveroudering. Het nadeel van deze aanpak is dat alleen kan worden aangegeven of er al dan niet sprake is van functie-inhoudelijke kwalificatieverouderingen en geen inzicht wordt verkregen in de mate waarin deze zich voordoet.

Het meten van factoren die functie-inhoudelijke kwalificatieveroudering beïnvloeden

In de literatuur worden verschillende factoren genoemd die mogelijk een rol kunnen spelen bij functie-inhoudelijke kwalificatieveroudering. Allereerst zijn dat organisatorische ontwikkelingen als reorganisaties en het vernieuwen van managementsystemen (Pillay, 1998, Thijssen, 1997a, Watkins en Marsick, 1993) die veelal grote veranderingen van de functie-inhoud met zich meebrengen. Organisatorische ontwikkelingen zijn veelal het gevolg van grote veranderingen in het bedrijfsleven: steeds vaker maakt massaproductie en specialisatie plaats voor op de consument afgestemd maatwerk (zie Van Wijnbergen, 1998), wat nieuwe, flexibele organisaties vereist en dus nieuwe eisen stelt aan werknemers.

Omdat er geen data met betrekking tot organisatorische ontwikkelingen beschikbaar zijn op individueel niveau, is een variabele gebruikt die per bedrijfssector het percentage bedrijven weergeeft dat reorganisaties heeft ondergaan. Er wordt verwacht dat een hoger percentage gereorganiseerde bedrijven een grotere kans op functieinhoudelijke kwalificatieveroudering tot gevolg heeft. 
Daarnaast vereist het toenemend gebruik van nieuwe technologieën (zie Pillay, 1998) en (Watkins en Marsick, 1993) eveneens andere kwalificaties binnen eenzelfde functie. Ook bij het in kaart brengen van deze ontwikkelingen is het niet mogelijk gegevens op individueel niveau te gebruiken. $\mathrm{Er}$ is daarom gebruik gemaakt van de mate van informatisering ${ }^{4}$ van het beroep waarin een werknemer werkzaam is. Naarmate het gebruik van informatie-technologie in iemands functie groter is, zal ook de invloed van ontwikkelingen op het gebied van informatietechnologie groter zijn en zal de kans op functie-inhoudelijke kwalificatieveroudering naar verwachting groter zijn.

Ook economische ontwikkelingen (Watkins en Marsick, 1993, Van Vliet, 1997) kunnen van invloed zijn op de functie-inhoud in bepaalde beroepsgroepen en daarmee ook een oorzaak zijn van functie-inhoudelijke kwalificatieveroudering. Belangrijke economische ontwikkelingen op dit punt zijn de ontwikkelingen die de internationale concurrentiepositie kunnen beïnvloeden zoals bijvoorbeeld het toetreden van nieuwe concurrenten en het concurreren op buitenlandse markten. De Nederlandse economie heeft in hoge mate met deze tendensen te maken, zoals bijvoorbeeld gezien kan worden aan de ontwikkelingen in het aandeel van de export. Deze zijn spectaculair te noemen: tussen 1960 en 1990 steeg dit aandeel van 30 naar $60 \%$. Ook in de nabije toekomst zullen deze ontwikkelingen zich voortzetten: de SER (Sociaal Economische Raad, 1996) verwacht dat in het jaar 2015 meer dan $80 \%$ van de Nederlandse industriële productie zal worden geëxporteerd, terwijl de Nederlandse markt voornamelijk bediend zal worden door het buitenland. Om adequaat te kunnen reageren op dergelijke ontwikkelingen zijn bedrijven en hun werknemers genoodzaakt flexibel te zijn om zo hun kwalificaties op een adequaat niveau te houden.

Om economische ontwikkelingen te meten is een tweetal maatstaven gehanteerd. Allereerst wordt er een vraag gebruikt die betrekking heeft op het bedrijf of de vestiging waar de respondent werkt. Het gaat erom of het bedrijf goederen of diensten importeert of exporteert. Indien dat het geval is, ondervindt het bedrijf waarin de respondent werkzaam is meer economische invloeden en wordt verwacht dat de kans op functie-inhoudelijke kwalificatieveroudering toeneemt. Daarnaast is er een index gebruikt die de 'openheid' van een sector weergeeft (Zie ook De Grip c.s., 1998). Hoe groter het aandeel van de productie van een sector dat wordt geëxporteerd, des te meer staat de sector bloot aan internationale concurrentie en des te groter is de kans op functie-inhoudelijke kwalificatieveroudering.

Tot slot zijn er ook variabelen opgenomen die demografische ontwikkelingen moeten uitdrukken. Hierbij gaat het met name om de vergrijzing van de werkzame bevolking. De eerste opgenomen variabele is de leeftijd van de respondent. Het idee hierachter

4. Onder 'informatisering' wordt verstaan het percentage werknemers dat gewoonlijk of soms met een computer werkt. 
is dat oudere werknemers veelal langere tijd geleden hun initiële opleiding hebben gevolgd waardoor zij, indien zij geen aanvullende scholing volgen, dus eerder een verouderde opleiding zullen hebben. Deze werknemers zullen daarom vaker met functie-inhoudelijke kwalificatieveroudering geconfronteerd worden. De tweede gebruikte variabele meet de mate waarin de leeftijd van een werknemer hoger is dan de gemiddelde leeftijd in het beroep waarin deze werkzaam is. Deze variabele is gedefinieerd als de gemiddelde leeftijd in een beroep minus de leeftijd van de respondent. Als de respondent dus ouder is dan de gemiddelde leeftijd in zijn of haar beroep is deze variabele negatief. De reden voor het gebruik van deze variabele is dat oudere werknemers meer risico lopen op functie-inhoudelijke kwalificatie-veroudering naarmate de gemiddelde leeftijd binnen hun beroepsgroep lager is. Gelet op de definitie van deze variabele wordt een negatief verband verwacht: hoe ouder de respondent in vergelijking met de gemiddelde leeftijd in het beroep, hoe groter de kans op functie-inhoudelijke kwalificatieveroudering.

Naast deze variabelen zijn ook variabelen in de analyse opgenomen die betrekking hebben op activiteiten die werknemers kunnen ontwikkelen om functie-inhoudelijke kwalificatieveroudering te beperken of te voorkomen. Het betreft variabelen die verband houden met het volgen van (aanvullende) scholing en het vergroten van employability. Dit zijn wederom de variabelen die in tabel 3.2 worden genoemd.

\section{De relatie tussen kwalificatieveroudering en risicofactoren}

De wijze waarop bovengenoemde factoren de functie-inhoudelijke kwalificatieveroudering beïnvloeden is onderzocht met behulp van een binomiaal logit-model. Hierin wordt de kans dat de opleiding is verouderd als gevolg van veranderende werkzaamheden gerelateerd aan de overige variabelen. Figuur 3.2 geeft de resultaten hiervan weer. De statistische resultaten zijn te vinden in tabel B2 van de bijlage achterin dit rapport.

Uit figuur 3.2 blijkt dat de mate van informatisering en organisatorische ontwikkelingen per sector de kans op functie-inhoudelijke kwalificatieveroudering inderdaad vergroten. Naarmate werknemers veel ouder zijn dan de gemiddelde leeftijd in hun beroep, neemt ook de kans op deze vorm van kwalificatieveroudering toe.

De mate waarin het bedrijf waarin men werkt onder druk staat van internationale concurrentie blijkt daarentegen geen significant effect te hebben op de kans op functie-inhoudelijke kwalificatieveroudering. Mogelijk houdt dit verband met de aard van de data.

De opleidingsbereidheid en het mobiliteitsvermogen blijken de functie-inhoudelijke kwalificatieveroudering inderdaad te verminderen. Naarmate men een kortere tijd in een bepaalde functie werkzaam is, is de kans op kwalificatieveroudering kleiner. De 
opleidingsbereidheid van werknemers draagt duidelijk meer bij aan het verminderen van de kans op functie-inhoudelijke kwalificatieveroudering dan de andere opleidingsvariabele, de opleidingsduur. Deze laatste variabele heeft weliswaar het verwachte teken, maar is niet significant. Een mogelijke verklaring voor het verschil in effect van deze beide variabelen is dat de opleidingsduur uitsluitend betrekking heeft op het gevolgde initieel onderwijs terwijl de opleidingsbereidheid ook betrekking heeft op de bedrijfscursussen. Vermoedelijk zijn het juist die cursussen die de functie-inhoudelijke kwalificatieveroudering beperken.

Figuur 3.2

De relatie tussen functie-inhoudelijke kwalificatieveroudering, oorzaken, risico-verhogende factoren en effectieve scholings- en employabilityvariabelen

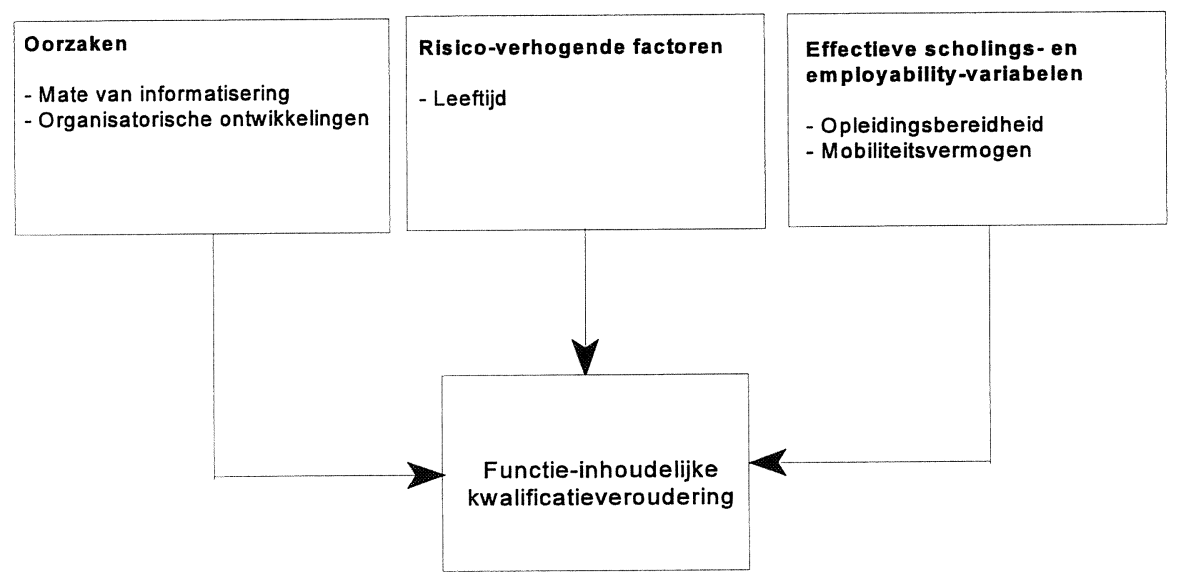

\subsection{Kwalificatieveroudering door marktontwikkelingen en bedrijfsspecifieke kwalificatieveroudering}

Kwalificatieveroudering door marktontwikkelingen kan optreden wanneer de werkgelegenheid in een bepaalde beroepsgroep of bedrijfssector krimpt, waardoor de getroffen werknemers moeten uitwijken naar een ander beroep of een andere bedrijfssector. Het kan ook voorkomen dat er van bedrijf gewisseld moet worden. Zo'n verandering van bedrijf kan gepaard gaan met bedrijfsspecifieke kwalificatieveroudering. Beide vormen van 'gedwongen' mobiliteit kunnen kwalificatieveroudering in de hand werken. Deze kwalificatieveroudering zal problematischer zijn naarmate het menselijk kapitaal van de werkenden in het bedrijf, de beroepsgroep of de bedrijfssector die getroffen wordt specifieker is. Het potentiële verlies aan kwalificaties is voor deze groep werkenden het grootst. 
Om kwalificatieveroudering te relateren aan marktontwikkelingen of bedrijfswisselingen wordt er voor een gefaseerde aanpak gekozen (vergelijk Teulings, 1990). Uitgangspunt zijn de personen die in het OSA-arbeidsaanbodsurvey van 1994 werkzaam waren. Kwalificatieveroudering door marktontwikkelingen of bedrijfsspecifieke kwalificatieveroudering kan zich bij deze groep op twee manieren manifesteren.

Allereerst kan kwalificatieveroudering door marktontwikkelingen ervoor zorgen dat werkenden hun baan verliezen. Kwalificatieveroudering wordt dan geïndiceerd door de uitstroom naar werkloosheid of niet-participatie; deze kans zal in de eerste analyse centraal staan.

Bij de groep werkenden die hun baan niet verliest, kan er echter ook sprake zijn van kwalificatieveroudering. In dat geval wordt de kwalificatieveroudering veroorzaakt door wisselingen van bedrijf, beroep, of bedrijfssector. Er is dan sprake van bedrijfsspecifieke kwalificatieveroudering of kwalificatieveroudering door marktontwikkelingen. Met name deze vorm van kwalificatieveroudering is echter moeilijk te meten. Idealiter zou er gekeken moeten worden naar de beschikbaarheid en de kwaliteit van kwalificaties bij werknemers en hoe die zich ontwikkelen in de tijd. Dat is echter met de verschillende databronnen die een beeld geven van de Nederlandse arbeidsmarkt niet mogelijk. Vandaar dat er gezocht is naar een proxy om deze vormen van kwalificatieveroudering in beeld te brengen. Het gaat hier om een vraag die ingaat op de mate van aansluiting tussen de kwalificaties en de huidige functie. Deze vraag kan worden beantwoord met 'goed', 'redelijk', 'matig' of 'slecht'. Aan deze antwoorden zijn scores toegekend van 4 ('goed') tot en met 1 ('slecht'). Er wordt gekeken naar de verandering tussen 1994 en 1996 in de antwoorden op deze vraag over aansluiting tussen kwalificaties en werk. Wanneer de aansluiting tussen kwalificaties en de huidige functie met twee punten of meer verslechterd is, dan wordt aangenomen dat er sprake is van kwalificatieveroudering, hetzij door marktontwikkelingen hetzij bedrijfsspecifieke.

Het meten van factoren die kwalificatieveroudering door marktontwikkelingen of bedrijfswisselingen beïnvloeden

Voor de eerste analyse, waarin de uitstroom naar werkloosheid of niet-participatie centraal staat, worden er zowel verklarende variabelen op individueel niveau als ook macro-variabelen gebruikt. Er wordt verwacht dat de kans op uitstroom naar werkloosheid of niet-participatie positief samenhangt met de krimpende werkgelegenheid in de sectoren, beroepen, en opleidingen. Daarnaast worden er ook variabelen opgenomen waarvan verwacht wordt dat ze de kans op werkloosheid verkleinen. Het gaat onder andere om de in tabel 3.2 genoemde indicatoren. 
Om kwalificatieveroudering door marktontwikkelingen die geen werkloosheid tot gevolg hebben of door wisseling van het bedrijf waar men werkzaam is te verklaren, is gekeken naar veranderingen in de arbeidsmarktposititie op individueel niveau. Daarbij is er een aantal mogelijke ontwikkelingen te onderscheiden:

- veranderingen van bedrijfssector;

- veranderingen van beroepsgroep;

- veranderingen van bedrijf.

Deze veranderingen zijn werkgelegenheidsontwikkelingen op individueel niveau, die het gevolg kunnen zijn van zowel ontwikkelingen in het bedrijf waarin men werkzaam is als ook marktontwikkelingen op macro-niveau. Daarnaast worden ook in deze analyse de in tabel 3.2 genoemde scholings- en employability- indicatoren opgenomen.

De relatie tussen kwalificatieveroudering en marktontwikkelingen of bedrijfswisselingen

De resultaten van de eerste analyse worden schematisch gepresenteerd in figuur 3.3. De statistische resultaten zijn te vinden in tabel B3 van de bijlage achterin dit rapport. De te verklaren variabele geeft aan of men in de periode 1994-1996 werkloos of niet-participerend geworden is. In eerste instantie zijn er in het model werkgelegenheidsontwikkelingen op bedrijfssector-, beroeps- en opleidingsniveau opgenomen. Daarbij wordt de verandering van de vraag met name gemeten door de werkgelegenheidsontwikkelingen op het niveau van de opleidingen. Deze variabele meet in feite ook alle onderliggende verschuivingen in de sector- en beroepenstructuur van de werkgelegenheid (ROA, 1997). De werkgelegenheidsveranderingen op het niveau van bedrijfssectoren en beroepen kunnen gezien worden als een correctie-variabele: een negatieve werkgelegenheidsontwikkeling in een bepaald opleidingstype kan er weliswaar voor zorgen dat iemand een hogere kans heeft op uitstroom naar werkloosheid of niet-participatie, maar hoeft, afhankelijk van de bedrijfssector of het beroep waarin men werkzaam is, toch niet noodzakelijk daartoe te leiden. Uit de analyse blijkt echter dat de werkgelegenheidsontwikkelingen naar beroep of bedrijfssector niet significant zijn. De enige werkgelegenheidsontwikkeling die wel significant is, is de werkgelegenheidsontwikkeling per opleidingstype.

Verder blijkt dat een drietal van de in tabel 3.2 genoemde indicatoren de kans op werkloosheid of niet-participatie verkleinen. Opvallend is dat deze drie variabelen allemaal bereidheidsvariabelen zijn. De bereidheid tot het volgen van opleidingen en een flexibele instelling is blijkbaar veel meer van belang bij het voorkomen van werkloosheid of niet-participatie dan het vermogen daartoe. 
Figuur 3.3

De relatie tussen kwalificatieveroudering door marktontwikkelingen (kans op werkloosheid of non-participatie), oorzaken, risico-verhogende factoren en effectieve scholings- en employability-variabelen

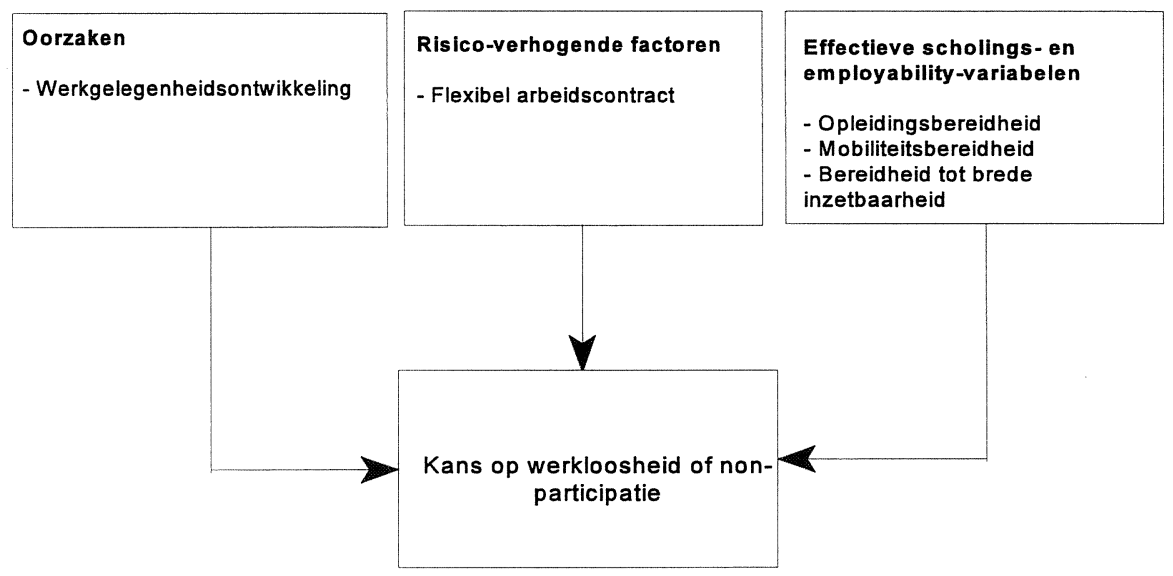

Daarnaast speelt het hebben van een flexibel arbeidscontract een belangrijke rol. Zoals uit de analyse blijkt, vergroot het hebben van een flexibel contract het risico op werkloosheid of niet-participatie aanzienlijk. In geval van krimpende werkgelegenheid of indien reorganisaties noodzakelijk zijn, kunnen werkgevers hun personeelsbestand immers eenvoudig inkrimpen door het beëindigen van flexibele arbeidscontracten.

In figuur 3.4 komen de resultaten voor de groep werkenden, die niet werkloos worden, maar mogelijk wel last hebben van kwalificatieveroudering, aan de orde. De statistiche resultaten zijn te vinden in tabel B4 in de bijlage achterin dit rapport. De veranderingen die werknemers kunnen ondergaan, zijn in het model zo gedefinieerd dat een werknemer maximaal 1 verandering kan ondergaan ${ }^{5}$. Ook werknemers die aangeven last te hebben van functie-inhoudelijke kwalificatieveroudering, worden in deze analyse niet meegenomen ${ }^{6}$.

5. Daarbij zijn erg onwaarschijnlijke veranderingen, zoals bijvoorbeeld verandering van bedrijfssector zonder van bedrijf te veranderen, buiten beschouwing gebleven.

6. Het blijkt overigens dat die groep werkenden die aangeeft te kampen te hebben met functieinhoudelijke kwalificatieveroudering in bijna alle gevallen niet van bedrijf, beroep of bedrijfssector gewisseld is. Dit houdt in dat deze vorm van kwalificatieveroudering in het algemeen niet tegelijkertijd voorkomt met kwalificatieveroudering door marktontwikkelingen of bedrijfsspecifieke kwalificatieveroudering en dat het gerechtvaardigd is ze buiten deze analyse te houden. 
Figuur 3.4

De relatie tussen kwalificatieveroudering door marktontwikkelingen en bedrijfsspecifieke kwalificatieveroudering (verslechterde aansluiting tussen opleiding en beroep), oorzaken, risicoverhogende en risico-verlagende factoren

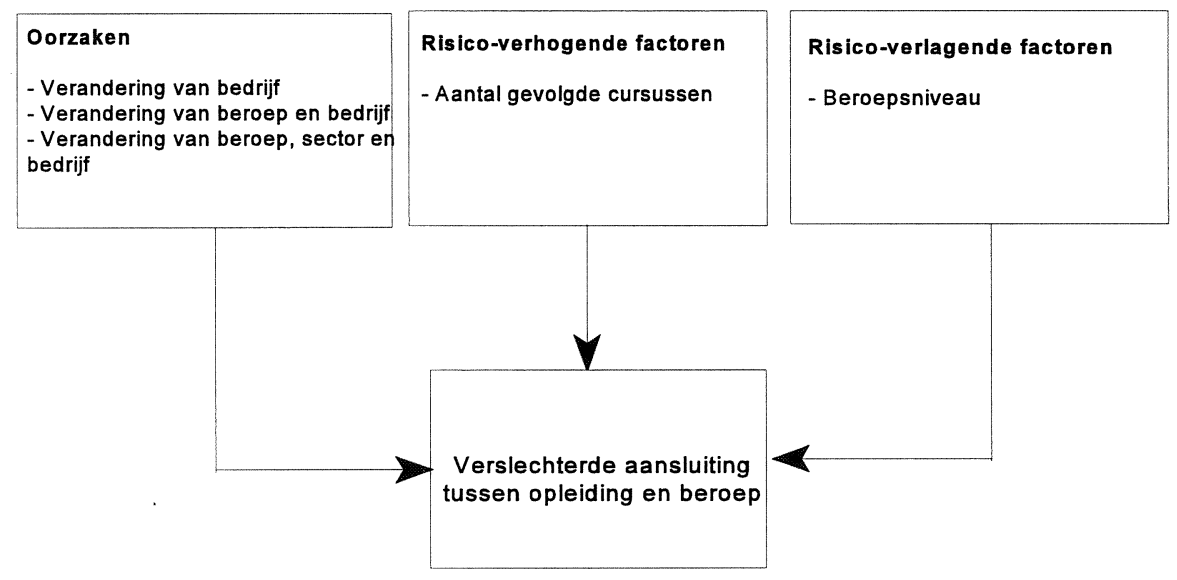

In eerste instantie zijn alle veranderings-variabelen in het model opgenomen. Het blijkt echter dat een aantal variabelen niet significant is; deze variabelen zijn daarom weggelaten. Van de variabelen die wel in het model zijn opgenomen, blijkt dat het tegelijk veranderen van beroep, bedrijf en bedrijfssector de grootste invloed heeft op de kans dat de aansluiting tussen opleiding en werk verslechtert. Een verandering van alleen de bedrijfssector heeft het op één na grootste effect. De verandering van beroep en bedrijf heeft een iets kleiner effect. Dit kan mogelijk verklaard worden uit het feit dat men door verandering van het beroep ook beter met de verandering van bedrijf kan omgaan.

In eerste instantie is ook geprobeerd de scholings- en employability-variabelen in het model op te nemen, maar geen van de zes factoren waarvan verwacht werd dat ze de kans op kwalificatieveroudering verkleinen blijkt enig significant effect te hebben. Het beroepsniveau van de werkende heeft wel een significant negatief effect op het risiso op kwalificatieveroudering door bedrijfswisselingen of marktontwikkelingen. Dat betekent dat werknemers in de hogere beroepen een kleinere kans hebben op een verslechtering van de aansluiting tussen opleiding en werk. Daarnaast blijkt het aantal gevolgde cursussen tot 1994 de kans op een verslechterde aansluiting positief te beïnvloeden. Daaruit kan worden opgemaakt dat diegenen die voorafgaand aan de enquêteperiode cursussen volgen, een hogere kans hebben op verslechterde aansluiting tussen kwalificaties en werk. Wellicht volgen juist die werkenden die al problemen hebben cursussen, en is het volgen van cursussen in onvoldoende mate een remedie voor kwalificatieveroudering, maar eerder een signaal ervan. Dit 
zou betekenen dat scholing in dit geval eerder een curatief dan een preventief karakter heeft.

\subsection{Conclusies}

In dit hoofdstuk stond de relatie tussen risicofactoren en de in het WSO onderscheiden vormen van kwalificatieveroudering centraal. Daartoe is voor iedere vorm van kwalificatieveroudering een analyse uitgevoerd die het risico dat een werknemer loopt om geconfronteerd te worden met kwalificatieveroudering (of de gevolgen daarvan) relateert aan het optreden van bepaalde risicofactoren enerzijds en scholings- en employability-variabelen anderzijds. Van de risicofactoren wordt verwacht dat ze de kans op kwalificatieveroudering vergroten; de scholings- en employability-variabelen zouden een tegenwicht moeten bieden aan kwalificatieveroudering en de kans daarop dus moeten verkleinen. In het volgende worden de resultaten van het hoofdstuk nog eens kort samengevat.

Het optreden van slijtage blijkt inderdaad positief samen te hangen met belastende arbeidsomstandigheden. Daarnaast hebben oudere werknemers een grotere kans op slijtage dan jongeren en hebben werknemers met een hoger beroepsniveau een kleinere kans op slijtage dan werknemers die een beroep op een laag niveau hebben. Scholings- en employability-variabelen zijn nauwelijks van belang bij het voorkomen van slijtage. Mobiliteitsbereidheid is de enige significante variabele, maar deze blijkt de kans op slijtage te vergroten. Dit is niet volgens de verwachting. Het feit dat werknemers die aangeven uit te zien naar een andere baan, dat ook vaak doen omdat ze de huidige werksituatie niet meer aankunnen, speelt hier mogelijk een rol.

Uit de analyses blijkt verder dat het risico op functie-inhoudelijke kwalificatieveroudering, zoals dat ook in het WSO-model verondersteld wordt, significant samenhangt met een aantal maatschappelijke ontwikkelingen. Daarbij blijken drie van de vier ontwikkelingen het risico op functie-inhoudelijke kwalificatieveroudering te vergroten. Het gaat allereerst om de technologische ontwikkelingen en de organisatorische vernieuwingen. Daarnaast vergroot ook de vergrijzing van de werkzame bevolking het risico op functie-inhoudelijke kwalificatie-veroudering. Het mobiliteitsvermogen en de opleidingsbereidheid (gebaseerd op het aantal post-initiële cursussen) blijken de kans op functie-inhoudelijke kwalificatieveroudering te verminderen. Het opleidingsvermogen (de totale opleidingsduur van initiële opleiding en cursussen) heeft daarentegen geen significant effect. Dit duidt erop dat met name het volgen van cursussen een belangrijk middel is om kwalificatieveroudering door technologische, organisatorische of demografische ontwikkelingen te voorkomen.

Kwalificatieveroudering door marktontwikkelingen kan zich op twee manieren manifesteren. Enerzijds kunnen werknemers werkloos of niet-participerend worden 
wanneer de werkgelegenheid in bepaalde beroepsgroepen of sectoren krimpt. Anderzijds kan het moeten wisselen van beroep of bedrijfssector kwalificatieveroudering veroorzaken. In de analyse wordt dit laatste gemeten door een verslechterde aansluiting tussen de kwalificaties en de huidige baan. Ook verandering van het bedrijf waarin men werkzaam is, kan problemen veroorzaken: er is dan sprake van bedrijfsspecifieke kwalificatieveroudering. Vandaar dat voor de werknemers die niet werkloos worden, de analyse voor kwalificatieveroudering door marktontwikkelingen en bedrijfsspecifieke kwalificatieveroudering geïntegreerd is.

Het risico op kwalificatieveroudering door marktontwikkelingen, dat zich uit door een hogere uitstroom van werkenden naar werkloosheid of niet-participatie, wordt inderdaad vergroot door de werkgelegenheidskrimp per opleidingstype. Werknemers met een flexibel arbeidscontract lopen een verhoogd risico, aangezien zij veelal de eersten zijn waarvan het contract wordt beëindigd in geval van krimpende werkgelegenheid. Verder zijn drie van de opleidings- en employability-variabelen van belang bij het verminderen van het risico op kwalificatieveroudering. Zowel opleidingsbereidheid, mobiliteitsbereidheid als bereidheid tot brede inzetbaarheid verkleint de kans op uitstroom naar werkloosheid of niet-participatie.

In de analyse waar de kwalificatieveroudering gemeten wordt door een verslechtering van de aansluiting tussen kwalificaties en huidige baan, kan er zowel sprake zijn van kwalificatieveroudering door marktontwikkelingen als van bedrijfsspecifieke kwalificatieveroudering. Uit de analyse komt naar voren dat een verandering van bedrijf, een verandering van beroep en bedrijf en een verandering van beroep, sector en bedrijf alle drie de kans op kwalificatieveroudering vergroten, waarbij laatstgenoemde verandering het grootste effect heeft. Het beroepsniveau heeft daarentegen een tegengesteld effect: werknemers met een hogere functie lopen minder risico op kwalificatieveroudering dan werknemers met een lage functie. Van de zes in tabel 3.2 genoemde scholings- en employability-variabelen leidt er geen enkele tot een vermindering van het risico op kwalificatieveroudering (gemeten door een verslechtering van de aansluiting tussen kwalificaties en huidige baan) door marktontwikkelingen of bedrijfswisselingen. Wel blijkt het aantal gevolgde cursussen tot 1994 de kans op deze vorm van kwalificatieveroudering te beïnvloeden. In tegenstelling tot het verwachte negatieve verband blijkt het aantal gevolgde cursussen echter de kans op kwalificatieveroudering te vergroten. Een mogelijke verklaring hiervoor is dat het juist de werkenden die al problemen hebben, zijn, die cursussen gaan volgen en dat scholing onvoldoende een preventieve remedie is voor kwalificatieverourdering. Scholing heeft hier derhalve eerder een curatief als een preventief karakter.

Ter afsluiting van dit hoofdstuk wordt er in tabel 3.7 een samenvattend overzicht gegeven van de oorzaken van de diverse vormen van kwalificatieveroudering en de effectiviteit van scholing en employability bij het voorkomen daarvan. 


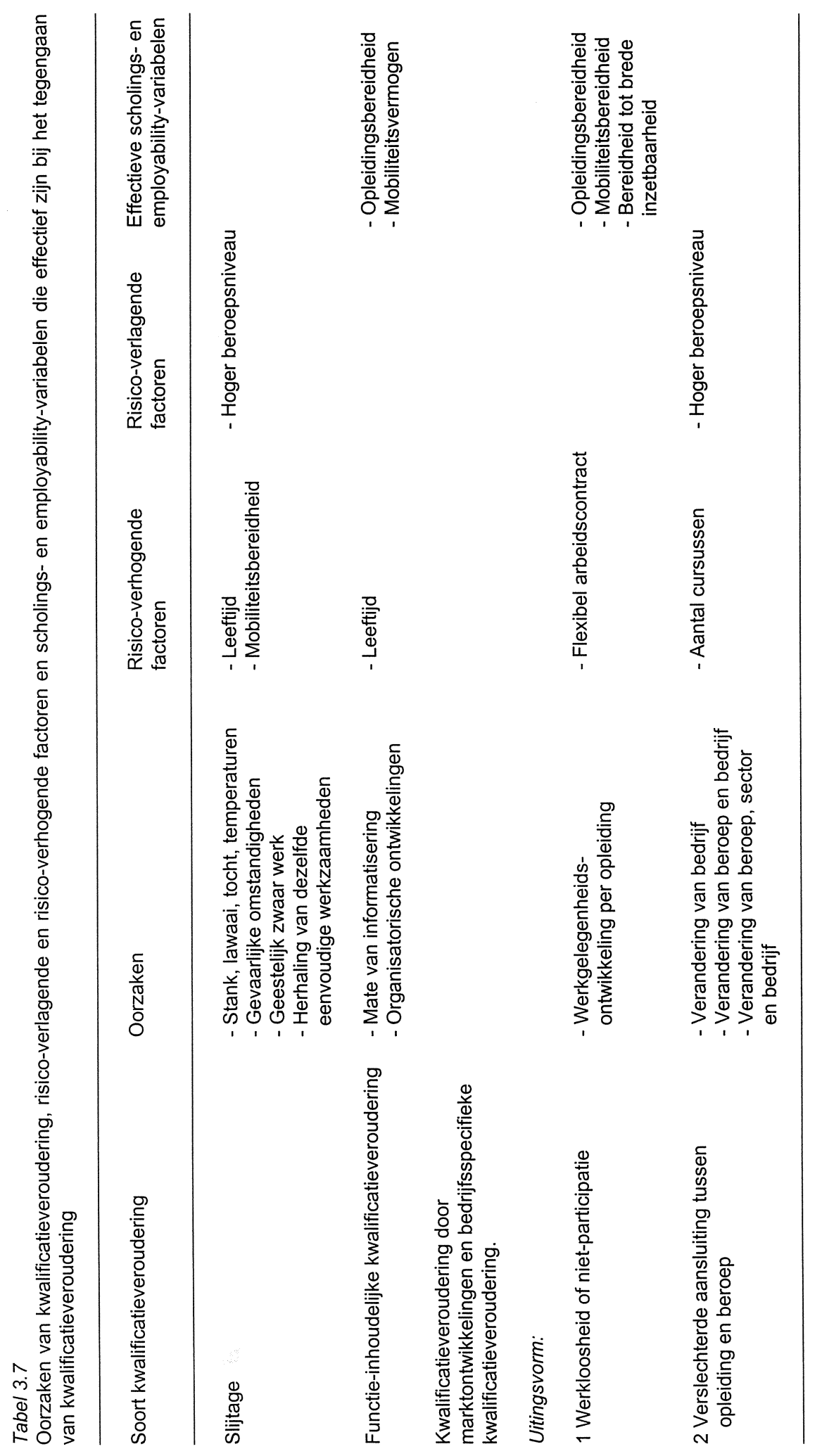




\section{Doelgroepen voor scholingsbeleid}

\subsection{Inleiding}

Het doel van dit hoofdstuk is om te komen tot een verbetering van de methodiek voor het bepalen van de doelgroepen voor scholingsbeleid zoals die in de WSO overzichtsrapporten (De Grip c.s., 1997a/b en ROA, 1998a/b) gebruikt wordt. Allereerst wordt er in paragraaf 4.2 nagegaan in hoeverre de verschillende scholings- en employability-variabelen met elkaar samenhangen. In de daaropvolgende paragraaf wordt aangegeven hoe de bepaling van de doelgroepen voor het scholingsbeleid op basis van de resultaten uit hoofdstuk 3 er uit zou kunnen zien. Deze analyse zal worden toegespitst op één van de in het vorige hoofdstuk geanalyseerde vormen van kwalificatieveroudering. Daarbij gaat het om de doelgroepen voor het scholingsbeleid op basis van het risico op functie-inhoudelijke kwalificatieveroudering.

\subsection{Samenhang tussen de verschillende scholings- en employability-varia- belen}

In Werkgelegenheid en scholing 1997 is bij de bepaling van de doelgroepen voor het scholingsbeleid gericht op behoud van werk de restrictie opgelegd dat zowel de scholingsparticipatie als de employability van werkenden tekort moeten schieten in relatie tot de risicofactoren. Uitsluitend indien groepen werkenden gekenmerkt werden door zowel een tekortschietende scholingsparticipatie als tekortschietende employability zijn zij als doelgroepen voor het scholingsbeleid aangemerkt. Impliciet is hier dus de veronderstelling gemaakt dat employabiity en scholing substitueerbaar zijn. Werkenden waarvan de scholingsparticipatie tekortschiet, maar de employabilty niet, worden niet als doelgroep aangemerkt, omdat is aangenomen dat een hoge mate van employability het schadelijk effect van de tekortschietende scholingsparticipatie op kwalificatieveroudering vermindert.

In een eerste poging inzicht te verkrijgen in de werkelijke relatie tussen scholing en employability, worden in deze paragraaf de resultaten van een correlatie-analyse beschreven die is uitgevoerd op de verschillende scholings- en employability-variabelen.

In tabel 4.1 wordt een overzicht gegeven van de mate waarin de diverse scholingsen employability-variabelen samenhangen. Naast de verschillende scholings- en employability-variabelen die in dit rapport aan de orde zijn geweest, zijn ook de variabelen afkomstig uit het rapport Werkgelegenheid en scholing 1997 (ROA, $1998 \mathrm{a} / \mathrm{b})$ in deze analyse opgenomen. In de tabel worden de correlaties weergegeven en wordt een indicatie gegeven van de significantie van de samenhang tussen de variabelen. 


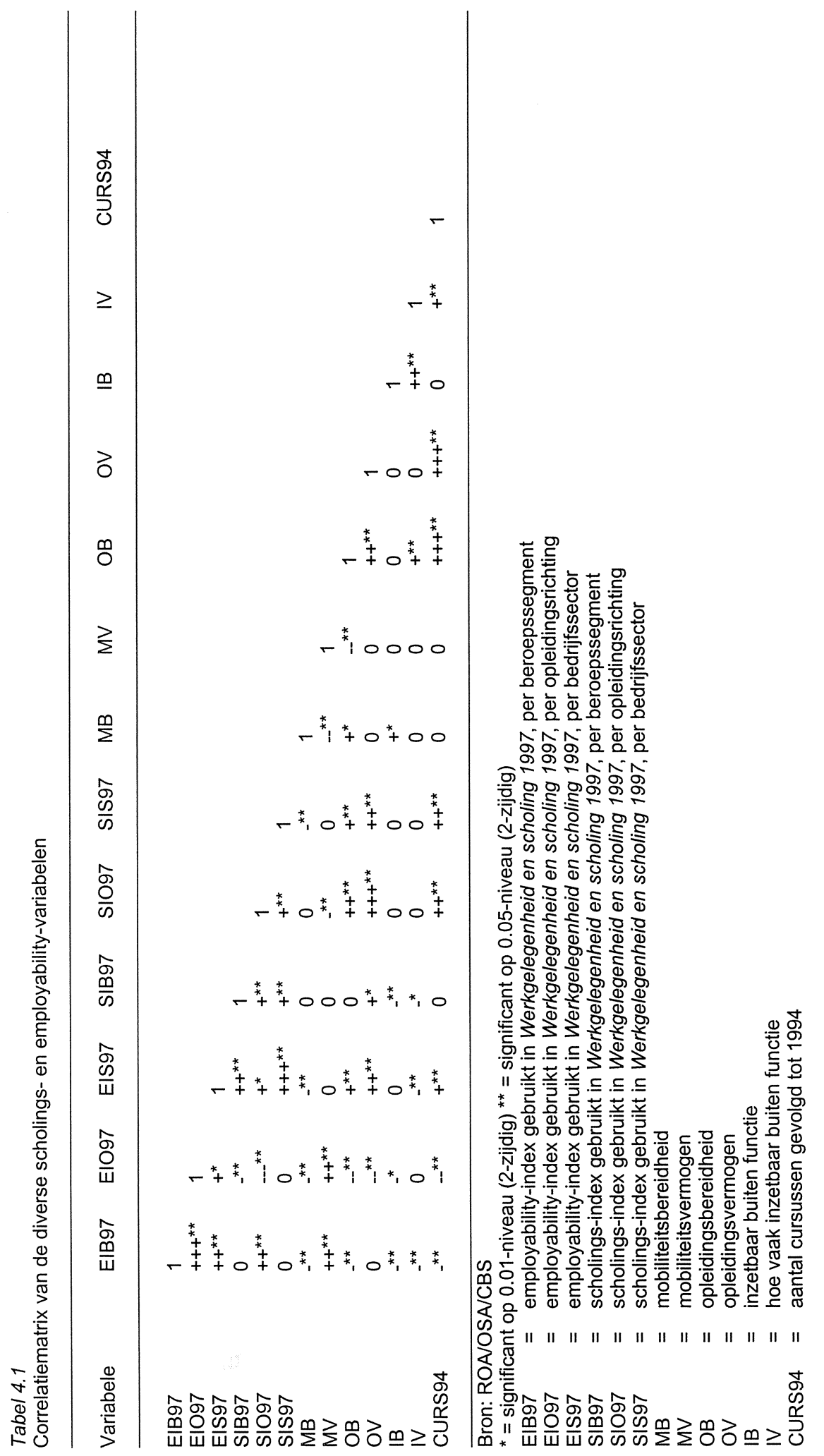


Uit de tabel komt naar voren dat de verschillende onderzochte employability-variabelen niet allemaal met elkaar gecorreleerd zijn. Inhoudelijk kan dit worden verklaard door het feit dat deze variabelen verschillende aspecten van employabilty weergeven. Voor de in hoofdstuk 3 gevonden relaties tussen kwalificatieveroudering enerzijds en scholing en employability anderzijds betekent het ontbreken van correlatie tussen de employability-variabelen dat deze afhankelijk zullen zijn van de keuze van de employability-variabele. De drie employability-indices voor respectievelijk beroepen, opleidingen en bedrijfssectoren die in Werkgelegenheid en scholing 1997 zijn gebruikt, zijn wel allen duidelijk met elkaar gecorreleerd. De index voor beroepen hangt sterker samen met die voor opleidingen dan met die voor bedrijfssectoren. De correlaties zijn respectievelijk 0.31 en 0.14 . Dit houdt vermoedelijk verband met de onderliggende sterkere verbanden tussen beroepen en opleidingen. Beroepen zijn veelal sterker verbonden met opleidingen dan met de sectoren waarin die beroepen kunnen worden uitgeoefend.

De verschillende onderzochte scholingsvariabelen hangen onderling vaker met elkaar samen. Dat is niet verrassend, omdat ze vergelijkbare aspecten van scholing weergeven. De consequentie van de gevonden correlatie tussen de verschillende scholingsvariabelen is dat het voor de in hoofdstuk 3 gevonden relaties tussen kwalificatieveroudering enerzijds en scholing en employability anderzijds weinig verschil maakt welke van deze scholingsvariabelen wordt gebruikt.

Er zijn geen eenduidige verbanden te ontdekken tussen employability- en scholingsvariabelen. Dat betekent dus dat de wijze waarop scholing en employability met elkaar samenhangen sterk afhankelijk is van de gekozen combinatie van variabelen. Wanneer in het bijzonder wordt gekeken naar het verband tussen de variabelen die in Werkgelegenheid en scholing 1997 zijn gebruikt om scholing en employability weer te geven, blijkt hier evenmin een eenduidige relatie te bestaan. Voor de verschillende bedrijfssectoren en opleidingsrichtingen worden respectievelijk een positieve en een negatieve correlatie aangetroffen. Bezien vanuit de invalshoek van beroepssegmenten blijkt zelfs helemaal geen significante correlatie aanwezig. Vanwege het ontbreken van een eenduidige relatie tussen scholing en employability lijkt enige terughoudendheid dan ook geboden bij het opleggen van de restrictie dat werkenden uitsluitend kunnen worden aangemerkt als doelgroep voor het scholingsbeleid gericht op het behoud van werk als zowel scholingsparticipatie als employability tekortschiet.

\subsection{Doelgroepen voor het scholingsbeleid als gevolg van functie-inhoudelijke kwalificatieveroudering}

In deze paragraaf zal worden nagegaan op welke wijze de doelgroepen voor het scholingsbeleid gericht op het voorkomen van kwalificatieveroudering kunnen worden getraceerd. Deze analyse zal worden toegepast op één van de in het vorige hoofdstuk geanalyseerde vormen van kwalificatieveroudering: de functie-inhoude- 
lijke kwalificatieveroudering. Bij deze analyse zal worden aangesloten bij de in paragraaf 3.4 gevonden risicofactoren en mogelijke remedies tegen functie-inhoudelijke kwalificatieveroudering. Het betreft hier de significante risicofactoren organisatorische ontwikkelingen en technologische ontwikkelingen. Deze risicofactoren worden nog versterkt als werkenden ouder zijn dan de gemiddelde leeftijd binnen hun beroepsgroep. Daarentegen bleken de scholings- en employability-variabelen mobiliteitsvermogen en opleidingsbereidheid de functie-inhoudelijke kwalificatieveroudering die het gevolg is van deze risicofactoren af te remmen.

Bij het traceren van de doelgroepen voor het scholingsbeleid gericht op de groepen die het risico lopen op functie-inhoudelijke kwalificatieveroudering is gebruik gemaakt van data uit het OSA aanbodsurvey 1996. Evenals in Werkgelegenheid en scholing 1997 is vanuit drie invalshoeken getracht doelgroepen te identificeren: bedrijfssector, beroepssegment en opleidingsrichting. Het belangrijkste verschil in de aanpak met de wijze waarop in Werkgelegenheid en scholing 1997 de doelgroepen werden bepaald, is het feit dat hier voor de relevante scholings- en employabilityvariabelen een gezamenlijke index ${ }^{7}$ is bepaald als tegenwicht van de diverse risicofactoren. In Werkgelegenheid en scholing 1997 werden scholings- en employabilityvariabelen afzonderlijk aan de risicofactoren gerelateerd. Vervolgens werd de eis opgelegd dat beide variabelen tekort moesten schieten in relatie tot de risicofactoren waarmee de werknemers in een bepaalde groep werden geconfronteerd om een doelgroep voor scholing voor behoud van werk te kunnen zijn. Impliciet werd hier dus de veronderstelling gemaakt dat scholing en employability substitueerbaar zijn. Dat wil dus zeggen dat een voldoende hoge mate van employability het schadelijk effect van een tekortschietende scholingsparticipatie op kwalificatieveroudering vermindert. Zoals eerder al in paragraaf 4.2 werd aangegeven, is geen eenduidige relatie te ontdekken tussen scholing en employability en is enige terughoudendheid bij het opleggen van genoemde eis geboden. Op de nu gehanteerde manier om doelgroepen te bepalen wordt beter rekening gehouden met de relatie tussen employability en scholing zoals deze zich voor deze vorm van kwalificatieveroudering voordoet.

Een tweede verschil in methodiek houdt verband met het moment waarop gegevens geaggregeerd worden. In Werkgelegenheid en scholing 1997 is gebruik gemaakt van gegevens die werden vastgesteld op het hogere aggregatieniveau van de bedrijfssectoren, beroepssegmenten en opleidingsrichtingen. Daarentegen zijn hier alle gegevens eerst per individu bepaald en vervolgens geaggregeerd over bedrijfssec-

7. Hierbij is gebruik gemaakt van Z-scores van de afzonderlijke scholings- en employabilityvariabelen (mobiliteitsvermogen en opleidingsbereidheid), die zijn samengevoegd tot een enkele index. Vervolgens is hiervan wederom een Z-score bepaald. 
toren, beroepssegmenten of opleidingsrichtingen ${ }^{8}$. Omdat in een later stadium geaggregeerd wordt, zal minder informatie verloren gaan en kunnen de doelgroepen voor het scholingsbeleid gericht op behoud van werk nauwkeuriger worden bepaald.

Tabel 4.2

Doelgroepen voor het scholingsbeleid gericht op degenen die het risico lopen op functieinhoudelijke kwalificatieveroudering

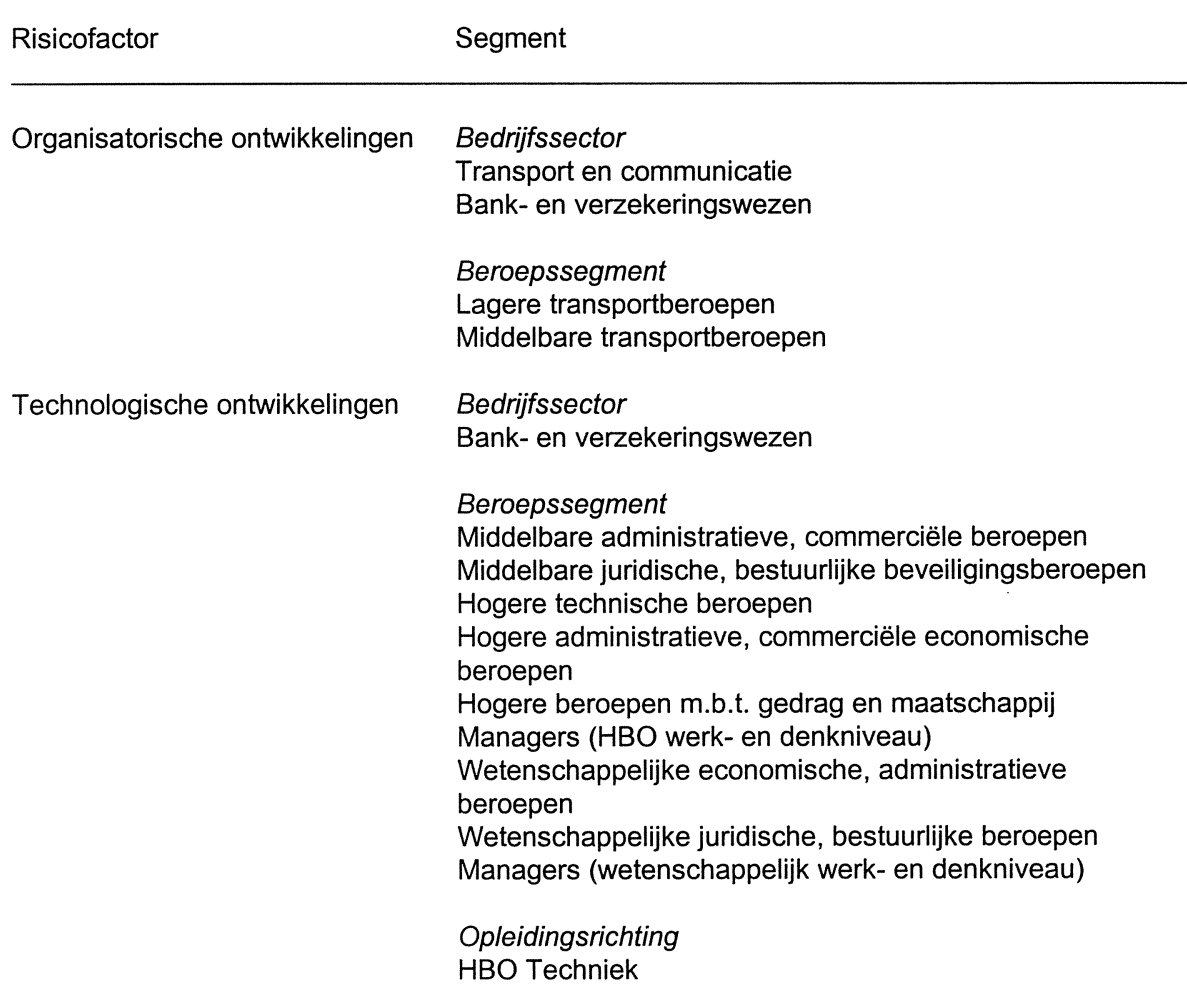

In tabel 4.2 wordt een overzicht gegeven van de groepen werkenden die uit de bovenstaande analyse naar voren komen als de doelgroepen voor het scholingsbeleid gericht op degenen die het risico lopen met functie-inhoudelijke kwalificatieveroudering te worden geconfronteerd. De risicoverhogende factor leeftijd in relatie tot de gemiddelde leeftijd per beroep is niet in de tabel opgenomen. Gebleken is namelijk dat in geen enkele bedrijfssector, beroepssegment of opleidingsrichting werknemers die ouder zijn dan de gemiddelde leeftijd binnen hun beroepsgroep als doelgroep voor het scholingsbeleid gericht op behoud van werk kunnen worden aan-

8. Bij de uiteindelijke bepaling van de doelgroepen zijn uitsluitend bedrijfssectoren, beroepssegmenten en opleidingsrichtingen beschouwd, waarvan tenminste 15 werkenden in het OSA aanbodsurvey 1996 zijn opgenomen. 
gewezen. Dat wil zeggen dat deze groepen werknemers voldoende opleidingsbereid zijn en over voldoende mobiliteitsvermogen beschikken om functie-inhoudelijke kwalificatieveroudering tegen te gaan. Het feit dat werknemers ouder zijn dan de gemiddelde leeftijd binnen hun beroepsgroep maakt hen op zich dus niet tot doelgroep voor het scholingsbeleid gericht op het behoud van werk. Op grond van de resultaten uit paragraaf 3.4 is het echter aannemelijk dat het optreden van technologische en/of organisatorische ontwikkelingen in combinatie met een leeftijd hoger dan de gemiddelde leeftijd binnen de beroepsgroep wel doelgroepen zou kunnen opleveren. Dit is echter niet verder onderzocht.

Werkenden in de bedrijfssectoren transport en communicatie en bank- en verzekeringswezen worden als doelgroep geïdentificeerd wanneer gelet wordt op organisatorische ontwikkelingen. Datzelfde geldt voor de beroepssegmenten lagere transportberoepen en middelbare transportberoepen. Dit is niet verrassend, aangezien deze beroepen het sterkst vertegenwoordigd zijn in de, eveneens als doelgroep aangemerkte, bedrijfssector transport en communicatie. Wanneer gekeken wordt naar opleidingsrichtingen zijn voor de risicofactor organisatorische ontwikkelingen geen doelgroepen aan te wijzen.

Technologische ontwikkelingen treffen eveneens de bedrijfssector bank- en verzekeringswezen. Gelet op het toenemende gebruik van technologie binnen deze sector, is dat allerminst verrassend. Beroepssegmenten die vanuit deze invalshoek een doelgroep vormen voor het scholingsbeleid gericht op behoud van werk, zijn met name economisch en administratief van aard, variërend van middelbaar tot wetenschappelijk niveau. Daarnaast worden ook hogere technische beroepen, managers op zowel HBO- als wetenschappelijk niveau en juridisch, bestuurlijke beroepen als doelgroep aangemerkt. Bij de opleidingen komen alleen de werkenden met de opleidingsachtergrond $H B O$ techniek als doelgroep voor het scholingsbeleid gericht op het behoud van werk.

De hier getraceerde doelgroepen voor het scholingsbeleid gericht op behoud van werk blijken duidelijk te verschillen van de in Werkgelegenheid en scholing 1997 geïdentificeerde doelgroepen. Zo konden er in Werkgelegenheid en scholing 1997 helemaal geen doelgroepen worden geïdentificeerd behorend bij de risicofactor organisatorische ontwikkelingen, terwijl dat met de nieuwe methodiek wel degelijk mogelijk is. Daarentegen bestaan er sterke overeenkomsten tussen de beide groepen beroepssegmenten die geconfronteerd worden met technologische ontwikkelingen en daaraan onvoldoende tegenwicht kunnen bieden door middel van scholing en een goede employability. 


\subsection{Conclusies}

In dit hoofdstuk is geprobeerd te komen tot een verbetering van de methodiek voor het bepalen van de doelgroepen voor het scholingsbeleid gericht op behoud van werk. Daartoe is eerst de relatie onderzocht tussen de verschillende scholings- en employability-variabelen middels een correlatie-analyse. Hieruit kon geen eenduidige relatie tussen scholing en employability worden afgeleid. Dit betekent dat enige terughoudendheid is geboden bij het opleggen van de restrictie dat groepen werkenden uitsluitend kunnen worden aangemerkt als doelgroep voor het scholingsbeleid gericht op het behoud van werk als zowel scholingsparticipatie als employability tekortschiet.

Vervolgens is nagegaan op welke wijze de doelgroepen voor het scholingsbeleid gericht op het voorkomen van kwalificatieveroudering kunnen worden getraceerd. Dit is toegespitst op functie-inhoudelijke kwalificatieveroudering en leverde aannemelijke resultaten op. De nieuwe methodiek leidt tot doelgroepen die deels verschillen maar zeker ook een bepaalde mate van overlap vertonen met de in Werkgelegenheid en scholing 1997 geïdentificeerde doelgroepen voor het scholingsbeleid gericht op het behoud van werk. Zo is bijvoorbeeld meer dan de helft van de in dit rapport geïdentificeerde doelgroepen per beroepssegment ook doelgroep wanneer de in WSO 1997 gebruikte methodiek wordt toegepast.

In principe kunnen voor elk van de in hoofdstuk 3 onderzochte soorten van kwalificatieveroudering op een dergelijke wijze doelgroepen voor het scholingsbeleid worden bepaald. De combinatie van verzamelingen van doelgroepen omvat derhalve alle doelgroepen voor scholing als gevolg van kwalificatieveroudering. Bij de toepassing van de methodiek op de overige vormen van kwalificatieveroudering dient echter wel het voorbehoud te worden gemaakt dat de benodigde data beschikbaar moeten zijn. Mogelijk kan het feit dat erg gedetailleerde gegevens benodigd zijn problemen veroorzaken bij de dataverzameling. 


\section{Conclusies}

In de integrale rapportages van het Werkgelegenheid en Scholing Observatorium (WSO) is een aantal veronderstellingen gemaakt omtrent de rol die scholing en employability kan spelen bij de bestrijding en voorkoming van kwalificatieveroudering. Zo wordt ondermeer aangenomen dat het volgen van scholing en/of een hoge mate van employability (het risico op) kwalificatieveroudering bij werknemers tegengaan. Ook is niet daadwerkelijk onderzocht in hoeverre de onderscheiden risicofactoren daadwerkelijk leiden tot kwalificatieveroudering. In dit derde themarapport van het Werkgelegenheid en Scholing Observatorium 1998 worden enkele veronderstellingen die centraal staan in het WSO empirisch getoetst, teneinde mogelijke verbeteringen in de methodiek aan te brengen.

$\mathrm{Na}$ een inleidend hoofdstuk waarin de doelstellingen van het rapport duidelijk worden gemaakt, wordt in hoofdstuk 2 aandacht besteed aan de scholing van werkenden. In dit hoofdstuk is in het bijzonder ingegaan op de betekenis van scholing die gericht is op het tegengaan van kwalificatieveroudering en de factoren die van invloed zijn op scholingsparticipatie. Dit gebeurt vanuit de optiek van zowel werknemers als bedrijven. Hoewel zowel werknemers als bedrijven in principe over meerdere alternatieven beschikken om met kwalificatieveroudering om te gaan, blijkt scholing voor beide partijen vaak het belangrijkste instrument om de nadelige gevolgen ervan tegen te gaan.

De effecten voor werknemers van het volgen van scholing, die gericht is op het tegengaan van kwalificatieveroudering, zijn afhankelijk van een tweetal factoren: de breedte van de door de scholing verworven competenties en de mobiliteitsmogelijkheden van de werknemers. Naarmate de verworven competentie breder is, zijn de loopbaanmogelijkheden als gevolg van de desbetreffende scholing beter. Werknemers die zich beperkt weten tot de secundaire arbeidsmarkt, ondervinden voor vrijwel alle verworven competenties minder positieve effecten dan werknemers die zich op interne arbeidsmarkten of vakdeelmarkten bevinden. Voor bedrijven geldt dat zowel de productiviteit als ook de bedrijfsprestaties positief samenhangen met de scholingsintensiteit.

In hoofdstuk 3 wordt er een centrale veronderstelling in de opzet van het WSO empirisch getoetst. Voor elk van de verschillende vormen van kwalificatieveroudering is de kans op het optreden van de desbetreffende kwalificatieveroudering gerelateerd aan het optreden van risicofactoren enerzijds en scholings- en employability-variabelen anderzijds. Alle in Werkgelegenheid en scholing 1997 gebruikte risicofactoren blijken inderdaad de kans op één of meerdere vormen van kwalificatieveroudering te vergroten. Scholing en employability gaan echter niet alle vormen van kwalificatieveroudering tegen. Zo blijken ze de kans op slijtage niet aantoonbaar te beïnvloeden en verhoogt het aantal gevolgde cursussen zelfs het risico op kwalificatiever- 
oudering door marktontwikkelingen en bedrijfsspecifieke kwalificatieveroudering. Vermoedelijk zijn het juist de werkenden die al problemen hebben die cursussen gaan volgen en is curatieve werking van scholing onvoldoende om de kwalificatieveroudering tegen te gaan. Overigens blijken scholingsparticipatie en employablity wel degelijk van invloed op de kans op werkloosheid en niet-participatie als gevolg van marktontwikkelingen. Ook voor de overige vormen van kwalificatieveroudering blijkt dat de kans op het optreden hiervan inderdaad wordt verkleind door scholingsparticipatie en een goede employability. Leeftijd blijkt in een aantal gevallen een risico-verhogende factor te zijn. Verder blijken werknemers met een flexibel arbeidscontract een hoger risico te hebben om werkloos of niet-participerend te worden als gevolg van marktontwikkelingen. Een risico-verlagende invloed blijkt in een aantal gevallen uit te gaan van het beroepsniveau.

Op basis van de resultaten uit hoofdstuk 3 wordt in hoofdstuk 4 geprobeerd te komen tot een verbeterde methodiek voor het bepalen van doelgroepen voor het scholingsbeleid gericht op het behoud van werk. Dit wordt toegespitst op één vorm van kwalificatieveroudering, te weten functie-inhoudelijke kwalificatieveroudering. Uit het ontbreken van een eenduidige relatie tussen scholings- en employability-variabelen kan worden geconcludeerd dat enige terughoudendheid is geboden bij het opleggen van de restrictie dat werkenden uitsluitend kunnen worden aangemerkt als doelgroep voor het scholingsbeleid gericht op het behoud van werk als zowel scholingsparticipatie als employability tekortschiet.

Hoewel de doelgroepen die middels de nieuwe methodiek zijn verkregen deels afwijken van de in Werkgelegenheid en scholing 1997 geïdentificeerde doelgroepen, zijn de resultaten zeker aannemelijk te noemen. In principe moeten op identieke wijze doelgroepen kunnen worden bepaald voor het scholingsbeleid gericht op het terugdringen van de overige onderscheiden vormen van kwalificatieveroudering. Mits er geen datarestricties bestaan, biedt de vernieuwde methodiek derhalve zeker perspectieven. 


\section{Literatuur}

Arrow, K. (1962), The Economic Implications of Learning by Doing, Review of Economic Studies 20 (juni), 155-173.

Baldwin, J. R. en J. Johnson (1995), Human Capital Development and Innovation: The Case of Training in Small and Medium-sized Firms (Analytical studies branch: research paper series 74), Ottawa: Micro-Economic Analysis Division, Statistics Canada.

Barro, R. J. en X. Sala-I-Martin (1995), Economic Growth, (1 ed.), New York: McGraw-Hill.

Bartel, A. P. (1991), Productivity Gains from the Implementation of Employee Training Programs (NBER Working Paper Series 3893), Cambridge MA: National Bureau of Economic Research.

Becker, G. S. (1980), Human Capital, a Theoretical and Empirical Analysis, with Special Reference to Education, (2 ed.), Chicago/London: The University of Chicago Press.

Bentlage, F. A., J. A. A. Van Duren, L. Franso, P. L. R. M. Van Hooft, en G. J. P. Smit (1989), Winst op Eigen Scholing, Resultaten van een Onderzoek naar de Relatie tussen Opleidingsinspanningen en Bedrijfsprestatie in Nederland, (Vol. projectnummer 2414), Den Haag: Ministerie van Sociale Zaken en Werkgelegenheid.

Carnevale, A., L. Gainer en J. Villet (1990), Training in America: The Organization and Strategic Rule of Training, San Francisco: Jossey-Bass.

Chelius, J.R. (1974), The Control of Industrial Accidents: Economic Theory and Empirical Evidence (Reprint Series 551), Durham: Institute for Research in the Behavioural, Economic and Management Sciences.

Cörvers, F. (1994), Human Capital Factors at the Firm Level, ROA-W-1997E, Maastricht

De Grip, A., L. F. M. Groot, J. A. M. Heijke en E. J. T. A. Willems (1990), De Aansluiting tussen Beroepen en Functies en de Relatie met Scholings- en Mobiliteitsprocessen, Organisatie voor Strategisch Arbeidsmarktonderzoek (OSA), Den Haag.

De Grip, A. en J. Hoevenberg (1996), Upgrading in the European Union, ROA-RM-1996/3E, Maastricht.

De Grip, A., J. Van Loo en J. Sanders (1998), Employability in Bedrijf: Naar een Employability Index voor Bedrijfssectoren, ROA-R-1998/10, Maastricht.

De Grip, A., M. Van Smoorenburg, L. Borghans en N. Jonker (1997a), Werkgelegenheid en Scholing 1996, ROA-R-1997/1, Maastricht.

De Grip, A., M. Van Smoorenburg, L. Borghans en N. Jonker (1997b), Werkgelegenheid en Scholing 1996, Statistische Bijlage, ROA-R-1997/1B, Maastricht.

De Koning, J., M.A. Spierings en C.T. Zandvliet (1996), Economische Aspecten van Arbeidsomstandigheden, een Literatuurinventarisatie in het Licht van de Behoefte aan Relevante Beleidsinformatie (Rapport SZW), Rotterdam: Nederlands Economisch Instituut.

Dekker, R. P. J., A. De Grip en J. A. M. Heijke (1995), Arbeidsmarktsegmentatie en Arbeidsmarktgedrag (OSA-werkdocument W127), Den Haag: Organisatie voor Strategisch Arbeidsmarktonderzoek.

Green, F., D. Ashton, B. Burchell, B. Davies en A. Felstead (1997), Are British Workers Getting More Skilled, Paper presented at the LOWER, London School of Economics.

Groot, W. (1998), Enterprise-related Training: A Survey, ongepubliceerd paper Amsterdam. 
ILO. (1995). World Employment 1995: An ILO Report, Geneva: International Labour Organization.

Kessels, J. W. M. (1996), Kennisproductiviteit, Deventer: Kluwer Bedrijfswetenschappen.

Kunnen, R., W. C. M. Praat, A. M. De Voogd-Hamelink en C. M. M. P. Wetzels (1997), Trendrapport Aanbod van Arbeid 1997 (OSA-rapport 25), Den Haag: Organisatie voor Strategisch Arbeidsmarktonderzoek.

Nijhuis, F. J. N. (1995), De Paradoxale Gezondheidseffecten van Arbeid, Maastricht: Oratie.

Nordhaug, O. (1993), Human Capital in Organizations, Competence, Training, and Learning, Bergen: Oxford University Press.

OECD (1996), Measuring what People Know, Human Capital Accounting for the Knowledge Economy, Paris: OECD.

Pillay, H. (1998), Cognitive Skills Required in Contemporary Workplaces, Studies in Continuing Education, 20 (1), 71-81.

ROA (1997a), De Arbeidsmarkt naar Opleiding en Beroep tot 2002, ROA-R-1997/7, Maastricht

ROA (1997b), De Arbeidsmarkt naar Opleiding en Beroep tot 2002, Statistische Bijlage, ROAR-1997/9b, Maastricht.

ROA (1998a), Werkgelegenheid en Scholing 1997, ROA-R-1998/1, Maastricht

ROA (1998b), Werkgelegenheid en Scholing 1997, Statistische Bijlage, ROA-R1998/1b, Maastricht.

Sicherman, N. (1990), Education and Occupational Mobility, Economics of Education Review, 9(2), 163-179.

Sociaal Economische Raad (1996), Sociaal Economisch Beleid 1996-2000 (SER Advies), Den Haag: SER.

Teulings, C. N. (1990), Conjunctuur en kwalificatie, Universiteit van Amsterdam, Amsterdam.

Thijssen, J. (1997), Employability en Employment: Terminologie, Modelvorming en Opleidingspraktijk, Opleiding en Ontwikkeling, 10 (10), 9-14.

Treu, T. (1992), Labour Flexibility in Europe, International Labour Review, 131 (4/5), 497-512.

Tuijnman, A. C. (1997), Economics of Adult Education and Training, Adult Education and Development, 49, 189-198.

Van Vliet, G. E. (1997), Veranderingen op de arbeidsmarkt: gevolgen voor onderwijs en scholing. In B. W. M. Hövels, W. J. Nijhof, A. M. L. Van Wieringen, en M. Van Dyck (Eds.), Beroepsonderwijs en Volwasseneducatie Nader Bekeken, Jaarboek 1996 van het Max Groote Kenniscentrum voor Beroepsonderwijs en Volwasseneneducatie (pp. 61-82), VUGA Uitgeverij, Den Haag.

Van Wijnbergen, S. (1998), Fiscaliteit, Onderwijs en Inactiviteit. In H. P. Huizinga (Ed.), Belas tingherziening in het Fin de Siècle, Preadviezen van de Koninklijke Vereniging voor de Staatshuishoudkunde 1998 (pp. 43-66), Utrecht: Koninklijke Vereniging voor de Staatshuishoudkunde.

Watkins, K. E. en V. J. Marsick (1993), Sculpting the Learning Organization, Lessons in the Art and Science of Systemic Change, (First ed.), San Francisco: Jossey-Bass Publishers. 


\section{Bijlage: Statistische Analyses}

Tabel B1

Risico op slijtage, standaardfout tussen haakjes

Variabele

Coefficiënt

Oorzaken

Stank, lawaai, tocht, hoge/lage temperaturen

0,4737

0,4913

Gevaarlijke omstandigheden

Geestelijk zwaar werk

Herhaling van dezelfde eenvoudige werkzaamheden

0,5525

0,6362

0,0238

0,8030

$-0,2868$

$-0,1116$

$-0,3568$

$-4,3938$

$(0,2209)^{\star \star \star}$

$(0,0545)^{\star * *}$

$(0,2060)^{\star * *}$

$(0,2045)^{\star * *}$

Leeftijd

Mobiliteitsbereidheid

Risico-verlagende factoren

, vrouw $=0)$

Flexibel jaarrooster

Constante

-2 Log Likelihood $=933,33$

$\mathrm{n}=2959$

${ }^{*}=$ significant op $15 \%$ niveau, ${ }^{* *}=$ significant op $10 \%$ niveau, ${ }^{* \star *}=$ significant op $5 \%$ niveau

Tabel B2

Risico op functie-inhoudelijke kwalificatieveroudering, standaardfout tussen haakjes

\section{Variabele}

Coëfficiënt

\section{Oorzaken}

Mate van informatisering per beroep

Organisatorische ontwikkelingen per sector

\section{0,0142}

0,0153

$(0,0043)^{\star \star \star *}$

$-0,0473$

$(0,0151)^{\star \star \star}$

Leeftijd in afwijking tot gemiddelde per beroep

$-1,7547$

$(0,2096)$

$(0,0554)^{* * *}$

$(0,2667)$

$(0,4784)$

Effectieve scholings-en employability-variabelen

Opleidingsbereidheid

$(0,8559)^{\star \star \star}$

0,0183

Mobiliteitsvermogen

$-3,6319$

$(0,3753)$

Constante

$(0,0112)^{*}$

-2 log likelihood $=403,808$

$\mathrm{n}=777$

${ }^{*}=$ significant op $15 \%$ niveau, ${ }^{* \star}=$ significant op $10 \%$ niveau, ${ }^{\star \star \star}=$ significant op $5 \%$ niveau 
Tabel B3

Risico op kwalificatieveroudering (kans op werkloosheid of niet-participatie) door marktontwikkelingen, standaardfout tussen haakjes

$\begin{array}{ll}\text { Variabele Coëfficiënt } & \end{array}$

Oorzaken

Werkgelegenheidsontwikkeling naar opleidingstype

$0,4634 \quad(0,2137)^{\star \star *}$

Risico-verhogende factoren

Flexibel arbeidscontract

$1,1154 \quad(0,2574)^{\star \star *}$

Effectieve scholings- en employability-variabelen

Opleidingsbereidheid

Mobiliteitsbereidheid

$-1,4022$

$-0,8949$

$(0,6625)^{\star \star *}$

Bereidheid tot brede inzetbaarheid

$-0,6119$

$(0,6083)^{\star}$

Constante

$-2,5307$

$-2 \log$ likelihood $=817,661$

$\mathrm{n}=1808$

${ }^{*}=$ significant op $15 \%$ niveau, ${ }^{* *}=$ significant op $10 \%$ niveau, ${ }^{* \star *}=$ significant op $5 \%$ niveau

Tabel B4

Risico op kwalificatieveroudering (verslechtering aansluiting tussen opleiding en baan) door bedrijfswisselingen en marktontwikkelingen, standaardfout tussen haakjes

Variabele

Coëfficiënt

Oorzaken

Verandering van bedrijf

1,3141

1,1137

$(0,4699)^{* * \star}$

Verandering van beroep en bedrijf

1,3857

$(0,5568)^{* * *}$

Verandering van beroep, sector en bedrijf

$(0,5212)^{\star \star \star}$

Risico-verhogende factoren

Aantal gevolgde cursussen tot 1994

0,0519

$(0,0323)^{*}$

Risico-verlagende factoren

Beroepsniveau 1996

$-0,3036$

$(0,1235)^{* \star \star}$

Constante

$-2,1658$

$(0,3295)$

-2 log likelihood $=630,529$

$n=1408$

${ }^{*}=$ significant op $15 \%$ niveau, ${ }^{* \star}=$ significant op $10 \%$ niveau, ${ }^{* \star \star}=$ significant op $5 \%$ niveau 


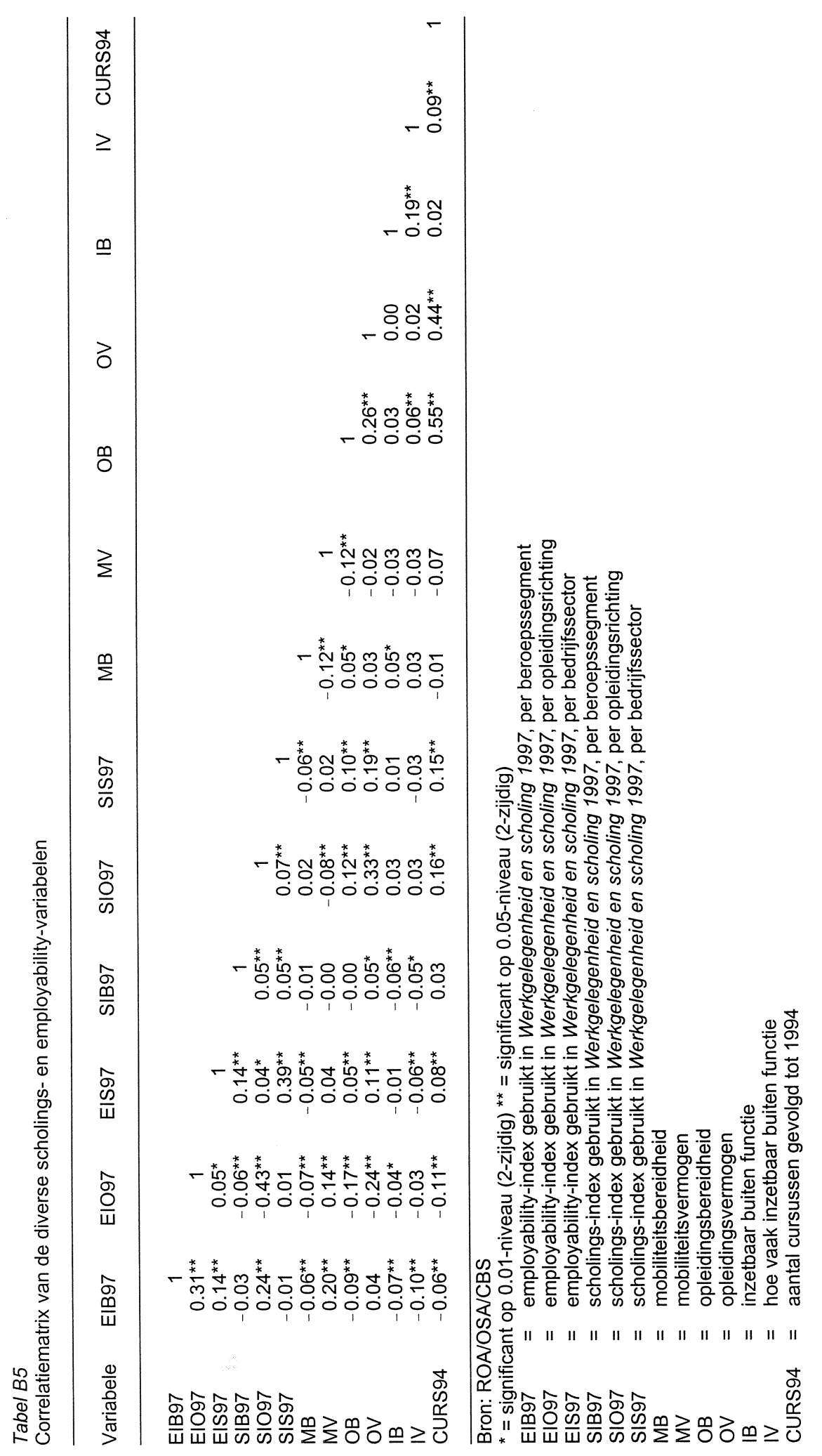

